\title{
Alabaster from the Ukrainian Carpathian Foredeep Basin in the architecture and sculpture of Kraków, Poland
}

\author{
Jacek RAJCHEL ${ }^{1, *}$, Tomasz ŚLIWA ${ }^{1}$ and Michał WARDZYŃSKI ${ }^{2}$ \\ 1 AGH University of Science and Technology, Faculty of Geology, Geophysics and Environmental Protection, Department \\ of General Geology and Geotourism, Al. A. Mickiewicza 30, 30-059 Kraków, Poland \\ 2 University of Warsaw, Institute of Art History, Krakowskie Przedmieście 26/28, 00-927 Warszawa, Poland
}

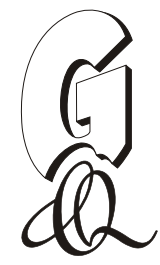

\begin{abstract}
Rajchel, J., Śliwa, T., Wardzyński, M., 2014. Alabaster from the Ukrainian Carpathian Foredeep Basin in the architecture and sculpture of Kraków, Poland. Geological Quarterly, 58 (3): 597-616, doi: 10.7306/gq.1185

Alabaster is a rock with low hardness, high coherence, fine-crystalline development and forms an optically "warm" surface when polished. It has been used as a sculpting, decorative and architectonic stone, often by civilizations of the Mediterranean Sea Basin. Alabaster in the architecture and sculpture of Kraków is mainly from the Middle Miocene (Badenian) and comes from deposits within the Ukrainian Carpathian Foredeep Basin, chiefly along its northern margin in the "Podolia rim". It was quarried around the mid-part of the Dnister River and its tributaries, from Lviv (Lwów) to Khotyn (Chocim), and mostly at Zhuravno (Żurawno). The alabaster quarried here was called Ruthenian, Polish, or Lvov "marble". Small quarries were also located at the front of the Carpathian overthrust, including the known deposit at Łopuszka Wielka. The Miocene alabaster has shades of white, yellow, green, brown, usually with differing spots or veins; often the rock is brecciated and partly semi-transparent. Alabaster has been quarried in the Polish Republic since the 16 th century, peaking (also in finished stone products) between the world wars. The authors present examples of alabaster usage in ecclesiastical edifices of Kraków, for instance in the Wawel Cathedral, St. Mary's Church, the churches of Dominican, Carmelite and Missionary clergy, and also in some secular buildings, e.g. the Jagiellonian Library.
\end{abstract}

Key words: alabaster, Carpathian Foredeep, Miocene, architecture, sculpture, Kraków, Zhuravno.

\section{INTRODUCTION}

The authors focused on examples of Miocene (Badenian) alabaster from the Ukrainian Carpathian Foredeep in the architecture (sensu lato) of Kraków. The use of alabaster has been discussed in geology, architecture, archaeology and art history papers (Łoziński, 1901; Tomkiewicz, 1912; Dromashko, 1955; Hornung, 1956; Krakowski, 1957; Koltun and Roskosh, 1969; Senkovskyi, 1972; Lyubchenko, 1981; Jagnyshchak, 1994, 1996, 2000; Syomochkyn and Jagnyshchak, 1999; Bevz, 2000; Dorosh, 2000; Glyembotska, 2000; Grankin, 2000; Popovych, 2000; Syomochkyn, 2000; Smyrnov, 2000; Rajchel, 2002, 2005; Lipińska, 2003, 2007; Korpysz, 2007, 2008; Wardzyński, $2010 a, b)$. This alabaster was quarried mainly in technically undeformed deposits of the Podolia area, located within the "Podolia rim" along the northern margin of the Ukrainian Carpathian Foredeep (Fig. 1). The quarries extend from the mid-part of the Dnister River and its tributaries, from the vicinity of Lviv to NW as far as Khotyn to SE, with Zhuravno (Żurawno) being the most prominent exploitation site. Alabaster quarrying in this re-

\section{* Corresponding author: jrajchel@geol.agh.edu.pl}

Received: March 7, 2014; accepted: June 20, 2014; first published online: August 6, 2014 gion, the eastern borderland first of the Polish-Lithuanian Commonwealth and after the World War I of the Republic of Poland, can be traced back to the mid-16th century. Minor quarries of alabaster were also located in the tectonically deformed Miocene strata at the front of the Carpathian orogen at Łopuszka Wielka and Bochnia.

Having studied polished specimen sections cut perpendicular to layering, Kwiatkowski (1972) distinguished four varieties of Miocene alabaster from the Polish Carpathian Foredeep. The first is alabaster with indistinct, misty and discontinuous relict lamination. The second includes mottled alabaster stones with a uniform rock background containing fine (1-6 mm), circular mottles. The third is represented by streaky alabasters, and the forth by brecciated alabasters whose nodes, most often circular and seldom angular in cross-sections, range between 0.5 and $2 \mathrm{~cm}$. In the Ukrainian section of the Carpathian Foredeep alabaster usually forms layers with a thickness of 10 to $40 \mathrm{~cm}$.

\section{CHARACTERISTICS OF ALABASTER}

The term alabaster (Latin alabastrites; Greek alabastros), a fine-crystalline, massive variety of gypsum rock, derives from the Greek name of the town of Alabastron in Lower Egypt near Thebes, where in ancient times such a rock was quarried (Żaba, 2006; Lipińska, 2011). Alabaster mainly belongs within evaporites formed in marine or, occasionally, lacustrine sedimentary 


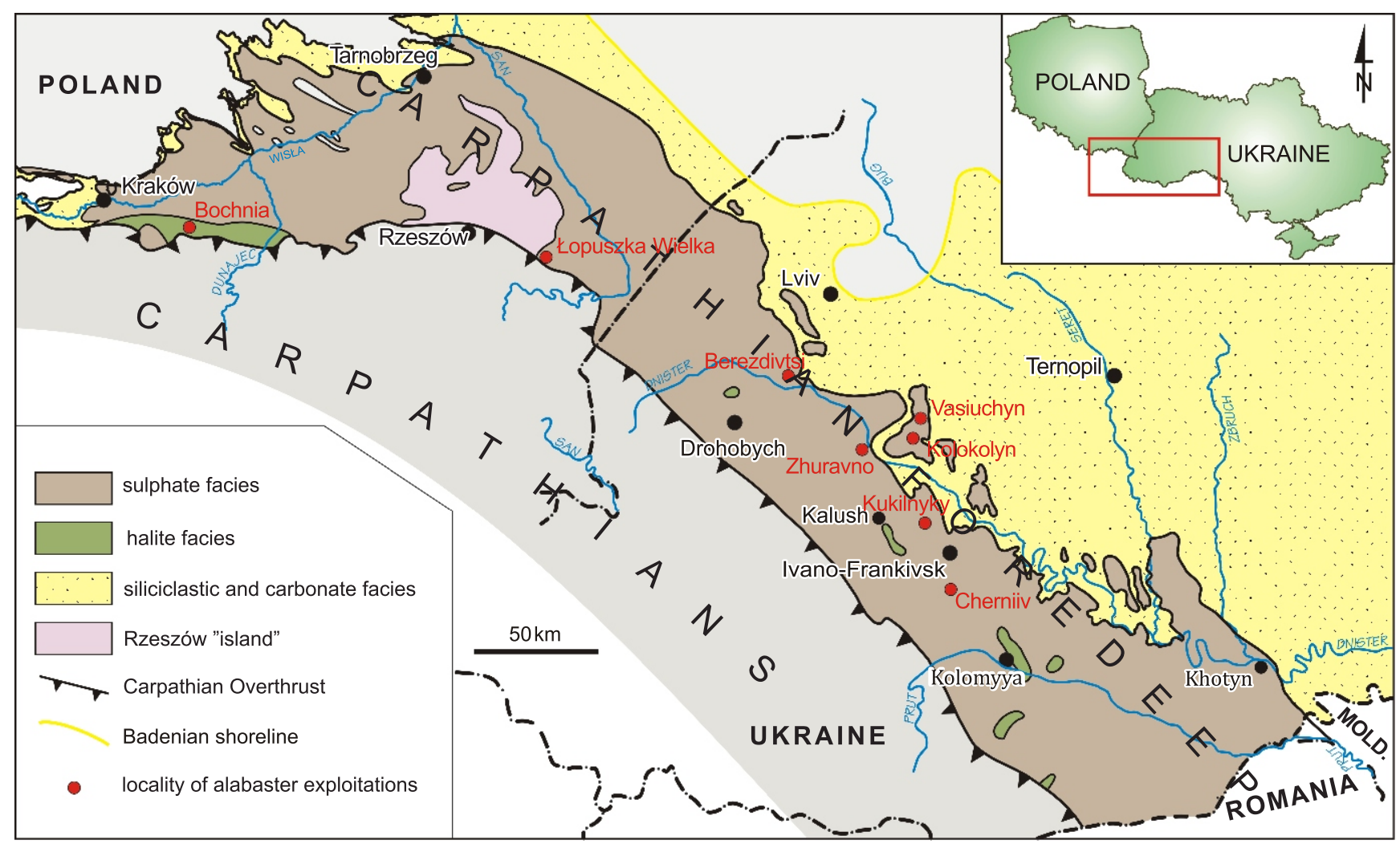

Fig. 1. Badenian sedimentary facies of the Polish and Ukrainian Carpathian Foredeep Basin with localization of main alabaster quarries (after Peryt, 1996, 2006; Bąbel, 2005, modified)

environments (Heflik et al., 1996). Less frequently alabaster deposits originate due to the hydration of anhydrite, or they occur within gypsum caps of salt deposits (Krajewski and Smulikowski, 1964). The mineral with the formula $\mathrm{CaSO}_{4} \cdot 2 \mathrm{H}_{2} \mathrm{O}$ is of hardness 2 on the Mohs scale, which means that it can be scratched with a nail. Alabaster may have various shades of white, yellow, green, brown or pink, most often with spots or veins that differ in colour, displays a characteristic crenulated lamination, and is partly semi-transparent. This wide range of colours is mostly caused by optical effects that occur when light travels through a crystalline mass, and also depends on the presence of trace admixtures such as clay minerals, limonite, hematite (Akerman, 1964), and dispersed organic matter. Alabaster forms thin layers with an irregular, granular top surface, in places covered with fine crystals of selenite (colourless, transparent gypsum). Alabaster is one of few rocks that can be artificially coloured due to it being prone to deep penetration of solutions, which have been used in manufacturing small fancy goods (Janeczek et al., 1991). Currently, alabaster is used as decorative facing slabs and also in the manufacture of small architectonic details: balustrades, cornices, fireplaces, banisters and similar. It is not suitable for outside decoration, nor as a material for floor slabs due to its low hardness. On the other hand, its low hardness combined with a highly coherent, finely crystalline development and the capability to take good polish makes alabaster an excellent sculptural material that has been used since antiquity.

Both in the past and present, there is considerable confusion as to the meaning of the term alabaster, particularly in archaeological literature and in art history. The term alabaster has been to describe rocks which are in fact calcite sinter; they have been given the names of calcite, oriental, Egyptian or antique alabaster. Following the rules of the current international petrographic classification, the term alabaster can only be applied to a massive, finely crystalline variety of gypsum.

\section{HISTORY OF ALABASTER QUARRYING IN THE CARPATHIAN FOREDEEP}

Alabaster is common in the Carpathian Foredeep in the Czech Republic, Poland, Ukraine and Romania (e.g., Rychlicki, 1913; Nowak, 1938; Kwiatkowski, 1972; Peryt, 1996, 2006; Babel, 2005). It usually forms thin layers between 10 to $40 \mathrm{~cm}$ in thickness, which occupy the lower part of the gypsum profile of the Tyras Suite of Middle Badenian age (Andreyeva-Grigorovich et al., 1997). The gypsum section is usually tens of metres thick and overlies Devonian, Upper Cretaceous and Lower Badenian strata, and is overlain by the Ratyn Limestone (e.g., Peryt et al., 2012). A characteristic marker bed (bed c) traceable over this whole area is composed of alabastrine gypsum. In addition, primary alabastrine gypsum forms thin intercalations with selenitic gypsum in units b, d and e (Kasprzyk, 1993; Peryt et al., 1997; Petrichenko et al., 1997; Peryt, 2001, 2013; Babel, 2005). Thicker (several metres in thickness) successions of secondary alabastrine gypsum occur within various parts of the gypsum profile (e.g., Kasprzyk, 1995; Peryt, 1996).

Alabaster quarrying in the Polish-Lithuanian Commonwealth began in the mid-16th century in the areas of the former Halych Ruthenia, Podolia and Pokuttya lands (Rychlicki, 1913; Gębarowicz, 1962, 1969; Wardzyński, 2010a). Back then the stone was called "marble", and only occasionally called Ruthenian, Pol- 
ish or Lvov alabaster. The centre of trade for this stone was in Lviv, from there both finished and semifinished products were distributed throughout Poland. Exploitation was occurring variably, with the best known quarries located at Vasiuchyn (Wasiuczyn) near Rogatin (Rohatyn), Cherniiv (Czerniejów), Kukilnyky (Kakolniki), Kolokolyn (Kołokolin) and the very first at Zhuravno. Others were located in the areas of the Svirzh (Świrz) and Gnyla Lypa (Gniła Lipa) rivers, Berezdivtsi (Brzozdowice) near Kuti (Kuty), Kalush (Kałusz) and Bukhachivtsi (Buchaczów), while minor quarries were active at a range of sites along the Dnister River (Rychlicki, 1913; Siemiradzki, 1922; Heflik, 1989; Rajchel, 2005).

Exploitation of the quarry at Vasiuchyn, Zhuravno and Kukilnyky probably began in the XII-XIII cc. (medieval architecture details in Halych and Drohobych; Bevz, 2000; Popovych, 2000). Before 1550 and in 1560 it was supervised by Hermann van Hutte of Aachen in Germany. He founded a company that dealt with quarrying, the manufacture of small alabaster accessories, stone carving, exporting final goods by land and river and the assembly of

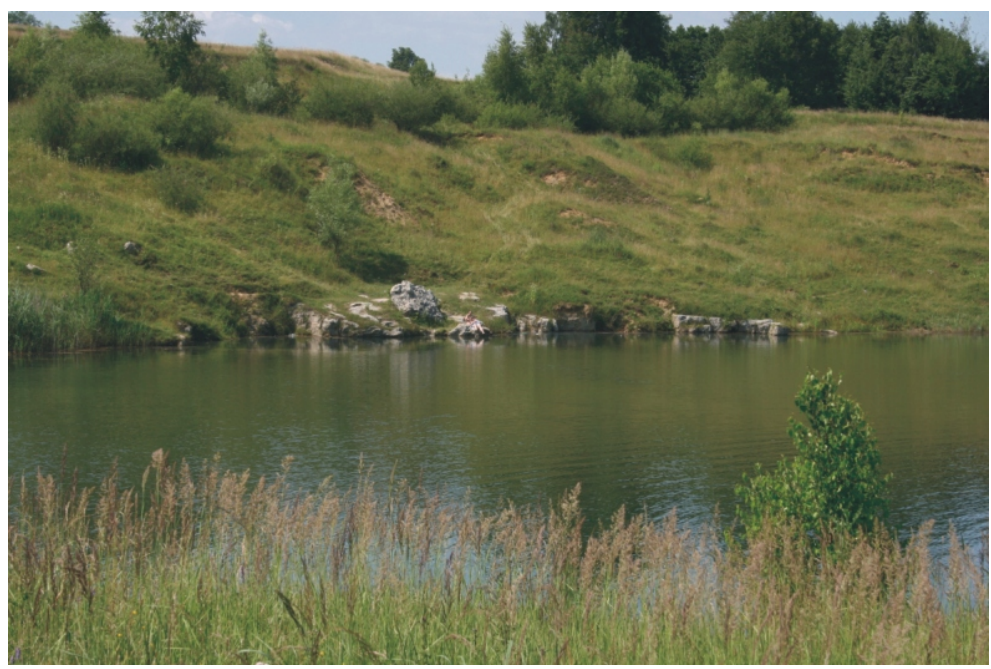

larger works at the customer's place of residence. He also had a branch of operations in Kraków, probably ran by Stanislas Furman. Expansion of such multisided activities that covered almost the whole area of the Commonwealth was facilitated by King Sigismund II Augustus, who granted van Hutte the privelege to use the title of court sculptor and specialist in breaking and tooling the "Ruthenian alabaster" (Gębarowicz, 1969; Maurin-Białostocka, 1979; Wardzyński, 2010a). The alabaster quarried at Vasiuchyn is semi-transparent, milky white or honey yellow and reveals small, brown colour changes. The rock is not currently quarried.

Another site of historic alabaster quarrying was Cherniiv, where stone breaking began in 1596. Initial operations were overseen by Andreas Bemer and Hans Pfister, who lived then in Lviv but was born in Wrockaw/Breslau (Lower Silesia, then part of the Kingdom of Bohemia, nowadays Poland) (Łoziński, 1901). The alabaster quarried there is whitish yellow with a dense network of fine veins; an excellent rock for sculpting. At Kukilnyky-upon-Bebilka, the locality belonging to the Lviv archbishopric, the alabaster quarried was of a dark grey or olive-green variety, often called "black Ruthenian marble". The workings at Kolokolyn quarried dark olive alabaster with small, white lenses (Wardzyński, 2010a) and were active until the 1990 s. In the abandoned quarry $5 \mathrm{~m}$ of finely crystalline gypsum with weakly expressed parallel lamination and $2 \mathrm{~m}$ of massive alabaster gypsum are exposed. Both rocks contain nodules of secondary, homogeneous texture.

In the 18th century alabaster quarrying in the Dnister River area almost came to a halt; in the 19th century Leonard Marconi resumed its exploitation as a building material at Berezdivtsi.

Zhuravno is the most renowned site of alabaster quarrying, with the beginning of rock exploitation going back to the second half of the 16th century (Fig. 2). The quarry was developed by Heinrich Horst, nicknamed the Agreeable (Zgodliwy), who came from Groningen in Friesland to Lviv, which was then the most buoyant artistic center working with "Ruthenian marble" (Gębarowicz, 1969; Lipińska, 2007; Wardzyński, 2010a, b). Horst was also active in the trade and distribution of the Zhuravno alabaster. One of his more spectacular transactions included exporting close to 130 cetnars (ca. 6.5 tons) of alabaster of various provenance, including those of Zhuravno, to Wrocław, where it was used by Friedrich Gross the Elder in execut-

Fig. 2. Abandoned quarry at Zhuravno, Bakotsyn Hill

$$
\text { Photo by T. Śliwa }
$$

ing a pulpit in the Church of St. Mary Magdalene (Gębarowicz, 1969; Wardzyński, 2010a).

The quarried bed of alabaster has a mean thickness of $6 \mathrm{~m}$ and reveals at least three varieties of the rock: a milky white alabaster, practically not semi-transparent; a milky white one, intersected by streaky, darker, semi-transparent small veins that form a network of small lenses; and an opaque whitish one, whose complex, patterned structure is composed of a dense network of breccia coloured by the compounds of iron and other metals into brown, greenish and steel grey (Wardzyński, 2010a). The grains of gypsum are $0.01-0.30 \mathrm{~mm}$ across; in places an oriented crystallisation of elongated grains of this mineral is visible (Agfanova et al., 1968).

The quarrying of and work upon the "Ruthenian alabaster" in the eastern territory of the Commonwealth stopped in the last thirty years of the 17th century due to a Cossack army, which devastated the quarries located along the Dnister and Stryi rivers and pillaged the whole of the Podolia and Pokuttya areas and the Ruthenian Voivodships during the Chmielnicki Insurrection. Further raids of Tatars and protracted wars with the Ottoman Empire made quarrying impossible until the end of the 17th century.

Quarrying and working of alabaster at Zhuravno resumed during Poland's twenty years of independence after World War I. A real renaissance of operations was initiated by Helena Duchess Czartoryska (née Skrzyńska) and her husband Kazimierz Duke Czartoryski. They also established a prospering workshop, called Alabastrownia, in which the rocks extracted were cut into format, worked on and polished (Fig. 3). They employed not only professional artisans, including master Bertini of Volterra (a famous centre of alabaster processing in the Apennines), but also eminent architects and sculptors, for instance Józef Szostakiewicz (1901-1981), an architectural engineer, and Jadwiga Horodyska (1905-1973), a sculptress (Kwiatkowska, 1993; Woźniak, 1964). Working together, they created a unique "Żurawno style" (Smirnow, 2005; Fig. 4). The Alabastrownia workshop manufactured not only sophisticated alabaster fancy goods, but also high-class decorations for church and secular interiors (Bunkiewicz, 1934). The products were often awarded with prestigious prizes as well as silver and gold medals at domestic and foreign exhibitions, e.g., the General Domestic Exhibition in Poznań, or in 1930 in Liège (a 


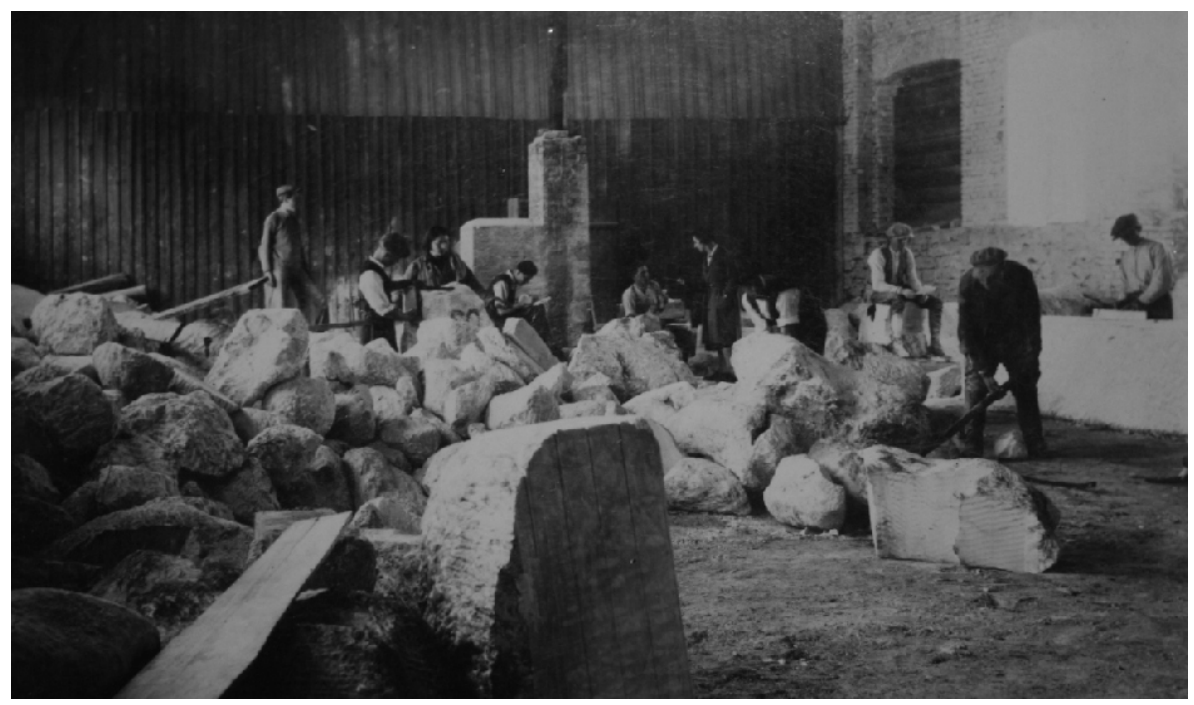

Fig. 3. Alabaster Workshops (no longer existing) of Duke Czartoryski's family at Zhuravno

Photo from the archive of Barbara Countess Czartoryska

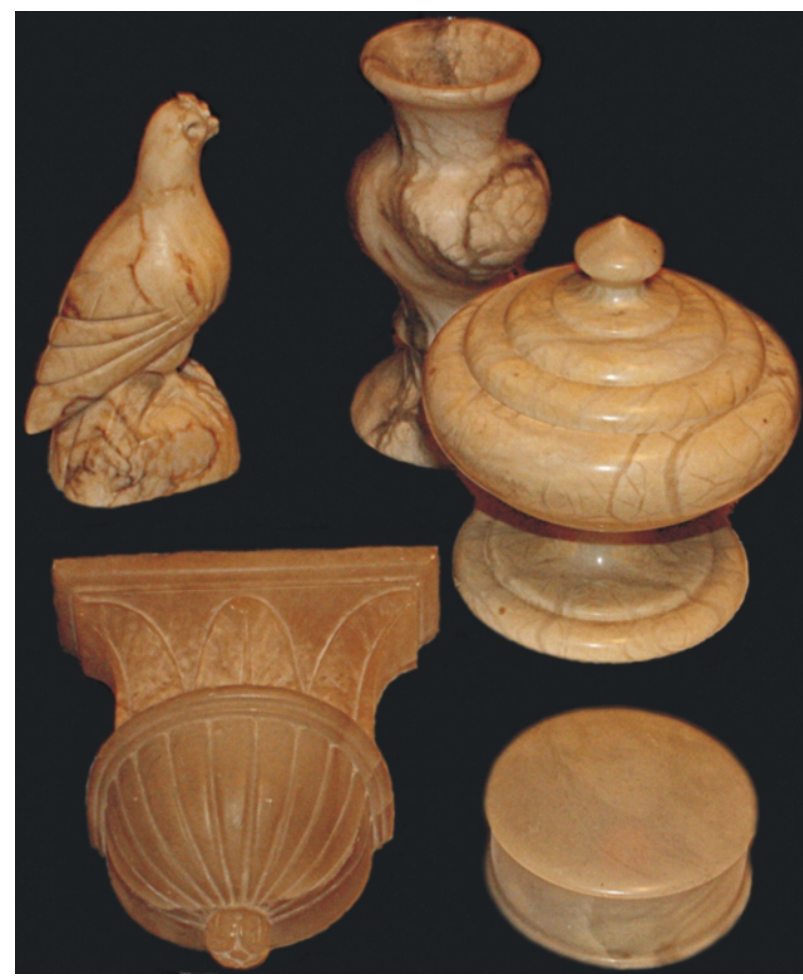

Fig. 4. Alabaster fancy foods; alabaster of Zhuravno

Photo from the archive of Barbara Countess Czartoryska

Grand Prix award). Beginning in the mid-1920s, the produce of the Czartoryski dukes was on exhibit at the annual Eastern Fair in Lviv. In the 1930s the Żurawno Possession was leased by a company of Ludwik Tyrowicz, a sole stone-mason plant active in quarrying alabaster for building purposes (Czyżowski, 1946-1948). After World War II the alabaster deposit at Zhuravno was quarried from 1960-1990 to manufacture facing slabs and decorative goods, with the volume of the blocks extracted reaching $6 \mathrm{~m}^{3}$ (Mitrofanov and Shpanov, 1970). The proven reserves of alabaster in the category $A+C_{1}$ are $0.6 \mathrm{mln}$ $\mathrm{m}^{3}$ (Syemchuk and Kshanovskiy, 1984). Now, this historic site of alabaster quarrying has been totally degraded.

Alabaster was extracted on a much smaller scale at several sites located within the borders of present-day Poland. Situated in the southern part of the Carpathian Foredeep is the alabaster deposit at Łopuszka Wielka near Kańczuga (present Subcarpathia; the former Przemyśl land of the Ruthenian Voivodeship), which was active in the 16th century (Szajnocha, 1901; Kozłowski, 1986). Mining resumed at the beginning of the 20th century on the initiative of Michael Scipio del Campo. It continued, on and off, after World War II until the 1980s. Underground extraction was hampered by the irregular structure of the deposit and considerable water inflows, both resulting in low outputs, thus mining was stopped despite a volume of proven reserves as high as $0.2 \mathrm{mln}$ ton. The alabaster of Łopuszka occurs as lenses up to several metres across (Garlicki, 1962; Heflik, 1989), and the rock is white and takes a good polish (Skalmowski, 1959). It was used in the reconstruction of many historical objects, such as the Royal Castle and the Łazienki and Wilanów palaces in Warszawa (Gajewski, 1989) and a Baroque chapel of the Oświęcim family in the Franciscan Church at Krosno.

In a similar geological structure, gypsum rocks, including alabaster, were quarried in the 18 and 19th century on Uzbornia Hill in the southern part of Bochnia (Flasza, 1998). Alabaster also occurs in the northern margin of the Carpathian Foredeep in Ponidzie, within gypsum rocks with a thickness of 30-40 m (Kwiatkowski, 1974). It is developed as a few thin intercalations, but without economic significance, grading into gypsum breccias (Heflik and Natkaniec-Nowak, 1996).

\section{ALABASTER IN THE ARCHITECTURE AND SCULPTURE OF KRAKÓW}

Alabaster has been used since the Middle Ages in the monumental architecture of Kraków as a decorative stone. It was applied mainly as a sculpting material in architectonic details and sepulchral art by Italian, German and Polish artists, particularly throughout the Renaissance period, and as a decorative 
stone in the 1930s. Initially it was used in ecclesiastical objects, and in more recent years in secular ones. The contribution of alabaster and its usage have diversified considerably through time, while its provenance is mostly unknown or only generally established.

The "Ruthenian alabasters" came to Kraków on a wider scale in the early 1560 s. This is corroborated by the sculptures made by van Hutte, which he sent in 1563 from Kraków to Wrocław. They included both secular and ecclesiastical works, including the altar of the Holy Trinity, not preserved today. The low price (170 of the then Polish zloty) suggests that the altar was executed in Poland by a local artist who promoted both his own artisanship and the stone material used (Gębarowicz, 1969). Made in Kraków at the turn of the 1550s, the architectonic details and reliefs cut in the Żurawno or Wasiuczyn alabasters are the works of designers and sculptors who came from the Apennine Peninsula. In a workshop in Kraków was executed a tomb of the Crown's magnate Jan Gabriel Tęczyńsk (deceased 1553), a castellan of Wojnicz and a voivode of Sandomierz, funded by his son Jan Stanislas Tęczyński. It found its way into the family mausoleum in the parish Church of the Canons Regular of the Lateran in Kraśnik in the years ca. 1553-1561 (Galicka and Smulikowska-Rowińska, 1961). A sculptor used the whitish alabaster of Zhuravno with a dense, irregular network of grey veins (Wardzyński, 2010a).

Besides Kraków and Lviv, there was only one stone workshop in the Lesser Poland region which at the end of the 16th century used the whitish and yellowish alabasters of Zhuravno or Vasiuchyn and the dark olive alabaster from Kukilnyky - the one run by Thomas Nikiel (deceased 1605), who probably came from the Netherlands (Wardzyński, 2010a, b).

To summarize, in the period ca 1560 to 1660 s in Lviv, the major sculptural centre in the Polish Crown Rus' in which various types of alabaster and stromatolite gypsum were used, the leading artists were mainly stonemasters from the Netherlands or the German Reich countries: Van Hutte, Horst, Bemer and Pfister. Some of them followed a Dutch principle of application of the three-coloured black-red-white gamut of stones; however, the colour palette was modified by some others.

\section{ALABASTER IN ECCESIASTICAL OBJECTS - EXAMPLES}

\section{THE ROYAL CATHEDRAL OF ST. STANISLAUS AND ST. WENCESLAUS AT WAWEL}

The Wawel Cathedral, a flagship of architecture and Polish history, boasts rich and diverse examples of decorative stones, including the alabaster from the Carpathian Foredeep. This stone appeared in the cathedral in the mid-16th century, and was used by eminent artists from the times of the Renaissance. In the Kraków mason workshop of Santi Gucci Fiorentino were sculpted alabaster backgrounds of the coat of arms cartouches, set in the royal tombs of Sigismund II Augustus (1574-1575), Anna Jagiellon (158-1584) and Stefan Báthory (1594-1595) in the Sigismund Chapel (Fischinger, 1969; Kozakiewiczowa, 1984; Kowalczyk, 1987; Darnowska-Łukaszewska, 1997; Wardzyński, 2010a)

The Chapel of the Purifying Holiest Virgin Mary. A first-rate example of alabaster fine arts in the cathedral is the Chapel of the Purifying Holiest Virgin Mary, also known as the Różyc, the Potocki family or the Padniewski chapel. It was decreed in 1381 by bishop Zawisza of Kurozwęki and completed in 1425 by Mikołaj of Kurozwęki, a Sandomierz voivode (Czy- żewski, 2002). Jan Michałowicz of Urzędów (born ca. 1525 deceased ca. 1583) was a sculptor who left in this chapel a permanent trace of his activity in "Ruthenian" alabaster. Called by Szymon Starowolski in Monumenta Sarmatarum (1655) the "Polish Praxiteles", he was the most outstanding Polish sculptor of the Renaissance period and the one who, alongside the Netherlanders, broke the hegemony of Italian artists working in Poland. Michałowicz probably apprenticed in Giovanni Cini's or Gian Maria Padovano's workshop (Kozakiewiczowa, 1983) and in his works successfully combined influences of the Italian Renaissance with Netherlands Mannerism. Already familiar with the "Ruthenian" alabaster (Gabriel's of Szadek plaque, 1563?, Dominican monastery; see former chapter), he used it in the statue of canon Andrzej Krajowski (deceased 1573) in the Wawel Cathedral. In 1572-1574 Michałowicz converted the former Gothic chapel into the Renaissance one, in which a Kraków bishop, Filip Padniewski, was buried. In Padniewski's tomb of dimensions $6 \times 2.5 \times 0.9 \mathrm{~m}$ the red nodular limestones of Stara Lubowla or Transylvania, the Pińczów limestone and the alabasters of Zhuravno and Vasiuchyn were used (Wardzyński, $2010 a, b)$. The extant, central part of this work presents the life-size figure of the late church official in the sansovinesque posture (i.e., shown as still living, reclined, half-sleeping, with his head propped on his hand and with his knee slightly bent). It was cut using three blocks of alabaster - featureless, yellowish rock with local white streaks. The bishop's face being realistically carved is one of outstanding achievements of the 16th-century sculpture of Poland (Kozakiewiczowa, 1983). The same rock was used to cut six small heads of putti (two in pendentives of arcades) and three eagles positioned on the sarcophagus mould. The archivolts were decorated with alabaster bosses (ten pieces), not previously used, resembling nail heads. In the pendentive at the junction of arches Michałowicz placed an alabaster crucifix. The backgrounds of the coat of arm cartouches in the backboards of a niche under the arches were made of the yellowish, textureless alabaster variety. The alabaster used in the Corinthian columns (voluted capitals decorated with acanthus leaves) has a brecciated and streaky texture and an intense honey yellow colour. In the tomb of bishop Padniewski there can be traced significant traits of Dutch art as well as the sculpting and graphic works of Cornelis Floris de Vriendt of Antwerp, after which Michałowicz patterned the three-coloured stone gamut and many elements of ornamental structure and details.

To the Kraków sculpture circle at the end of the 16th century can also be attributed the epitaph plaque of canon Andrzej Ciekliński (deceased 1591), sculpted as a semi-figure relief using a honey yellow, transparent alabaster. The same material was applied in four small coats of arms, and a pair of small machine-turned lonic columns in the highly veined Zhuravno alabaster variety was added at the turn of 19th century.

The Chapel of St. Mathias and St. Matthew. The Chapel of St. Mathias and St. Matthew, also called Lipskis' Chapel, was built in Gothic style in the first half of the 14th century, and later converted twice in the years 1630-1632 and 1743-1746. In the first stage of reconstruction, upon the inner western wall worked two outstanding Cracovian sculptors, the brothers Andrea and Antonio Castelli of Lugano, who erected a monumental tomb of Andrzej Lipski, a Kraków bishop (deceased 1631; Fig. 5). As in the remaining works of the Castelli brothers, the whole excellent figural decoration, i.e., resting on the sarcophagus the effigy of the mitered prelate, the figures of St. John the Baptist and St. Andrew, figures and small heads of angels and the figure of Christ Resurrected (Karpowicz, 2002), were carved in the semi-transparent alabaster of Vasiuchyn. The author of the second stage of modernization was a Roman, Francesco 
Placidi, esteemed in Kraków and throughout Lesser Poland. He also designed the tomb placed opposite the former, where a relative of bishop Andrzej, cardinal Jan Alexander Lipski, was buried in 1746 (Betlej, 1996). According to the extant and published contract, Rojowski declared two curving statues of personifications, two small angels near the coat of arms, figures of small rams and unicorns below the coffin and a putto above it, and a bust of the late cardinal. All these decorations survive almost fully intact. Rojowski, following the rules of the contract, cut the items in a creamy, textureless alabaster ".... without defects of any veins properly polished, which the said alabaster on his own expense to procure and fetch to Cracow from Bochnia or elsewhere master Rojowski will be obliged...". The work was priced at 2 thousand zloty. The annex to the contract of 27th July 1747 informs that a woodcarver of Kraków is obliged to erect a "gypsum pavilion" over the tomb in the form of a stuccowork presenting a screen with angels and putti, for which he was to be paid an additional sum of 400 zloty (Betlej, 2007).

With Rojowski and his apprentices are associated important, yellowish and olive-green alabaster elements located in a pair of imposing marble-stucco monuments to royal couples: the first of Michał Korybut Wiśniowiecki and Maria Eleonora von Habsburg and the other of Jan III Sobieski and Maria Casimira de la Grange d'Arquien, procured in the years 1758-1761 behind the chancel in the eastern wing of the ambulatory, following a design of Francesco Placidi. Low-relief portrait medallions of both couples as well as the bas-reliefs with episodes commemorating the battles of Chocim/Khotyn and Vienna, placed on the front walls of the two cenotaphs (Przybyszewski, 2012), were made of alabaster.

The Chapel of St. John the Baptist. The Chapel of St. John the Baptist of around 1350, also called Kościeleckis' Chapel or the Zadzik Chapel, is located in the southern wing of the ambulatory. In the 16th century it gained a new decor in conjunction with the burial of Andrzej Kościelecki (deceased 1515), a crown undertreasurer. As a result of the next major restructuring which was carried out in 1645-1647, a mausoleum of Jakub Zadzik, a Kraków bishop (deceased 1642), was erected following a design of Thomas Poncino, an attributed royal architect. The chapel, erected on a square layout, gained a cupola with stucco decoration (but without a drum), inner facings, a twosided portal, a splendid altar and a tomb, all of them of the "black" Debnik limestone and the pinkish vein calcite of Paczółtowice (Czyżewski, 2002). In the retable a white variety of alabaster set against the black limestone was used to give a contrasting effect. An undetermined sculptor of north-European provenance, probably the Dane Martin Christian Peterson of Copenhagen (deceased 1665) who was active at that time in Kraków, cut in the white alabaster figures of two St. Jacobs: the Elder and the Younger, many figures of angels, small heads of Cherubs in the type of mannerist espagnolettes in the upper steps of the column pedestals, and many floral and cartilage-auricular ornaments (Targosz, 1991; Karpowicz, 2003; Wardzyński, 2012a).

Of particular interest is the tomb statue of bishop Zadzik located on the eastern side. Its Corinthian columns, propped on a high pedestal and two-zone plinths, flank the middle part with an earing epitaph plaque and a cast in a bronze bust of the deceased. Above the capitals on the entablature there are alabaster figures of small angels holding the symbols of human vanity (Rożek, 1980). In the pedestal zone, on imposts can be seen small female heads cut in white alabaster that grades into the yellow variety. The ornamental necklaces of the heads and a denticulated margin of a vernacle are covered with gold leaves and paint. In addition to figural works, the chapel is decorated with a wealth of sculpting details. Panels are enlivened with Paczółtowice limestone and alabaster in the form of rectangular small plates either with a prismatic cut or flat, set into geometric patterns. The southern, i.e. window wall is an example. Its two-zone high plinth, stepped at the ends, connects the windowsill with the floor. The plinth background of the black limestone has an incrustation made of honey-yellow alabaster: the Veraicon (the Veil of Veronica, or Sudarium) supported by St. Veronica. It is further decorated with alabaster knots tying heavy garlands and bunches of flowers sculpted in a pink limestone, and alabaster cartouches with inserts of Paczóltowice limestone. The whole alabaster decoration is interconnected with small heads of lions placed on wide and tucked, hermed pilasters in the portal (Targosz, 1991; Karpowicz, 2003).

The same sculptor worked with the same alabaster material cutting six heads, espagnolettes, inside the lantern of the Chapel of St. Catherina of Alexandria (called also the bishop Gamrat or canon Andrzej Grochowski chapel). They are dated to the time of the chapel conversion in 1646-1649, in which Bartholomeo

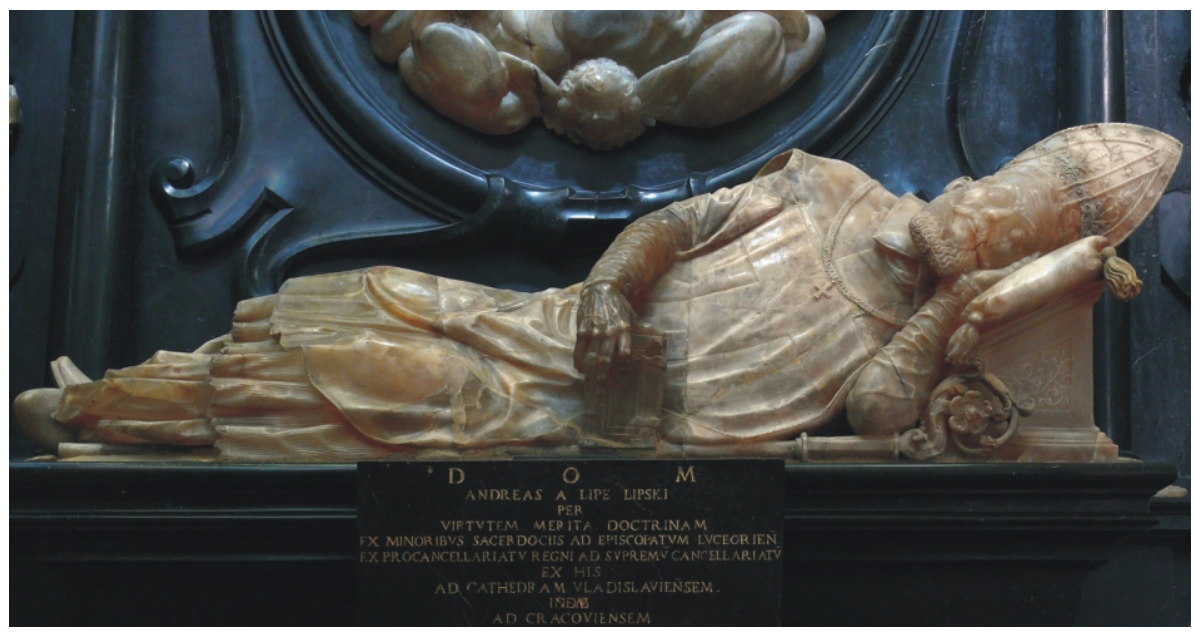

Fig. 5. Wawel Cathedral, Kraków; Lipskis' Chapel: the figure of Bishop Andrzej Lipski; alabaster of Vasiuchyn, sculptors: Andrea and Antonio Castelli 


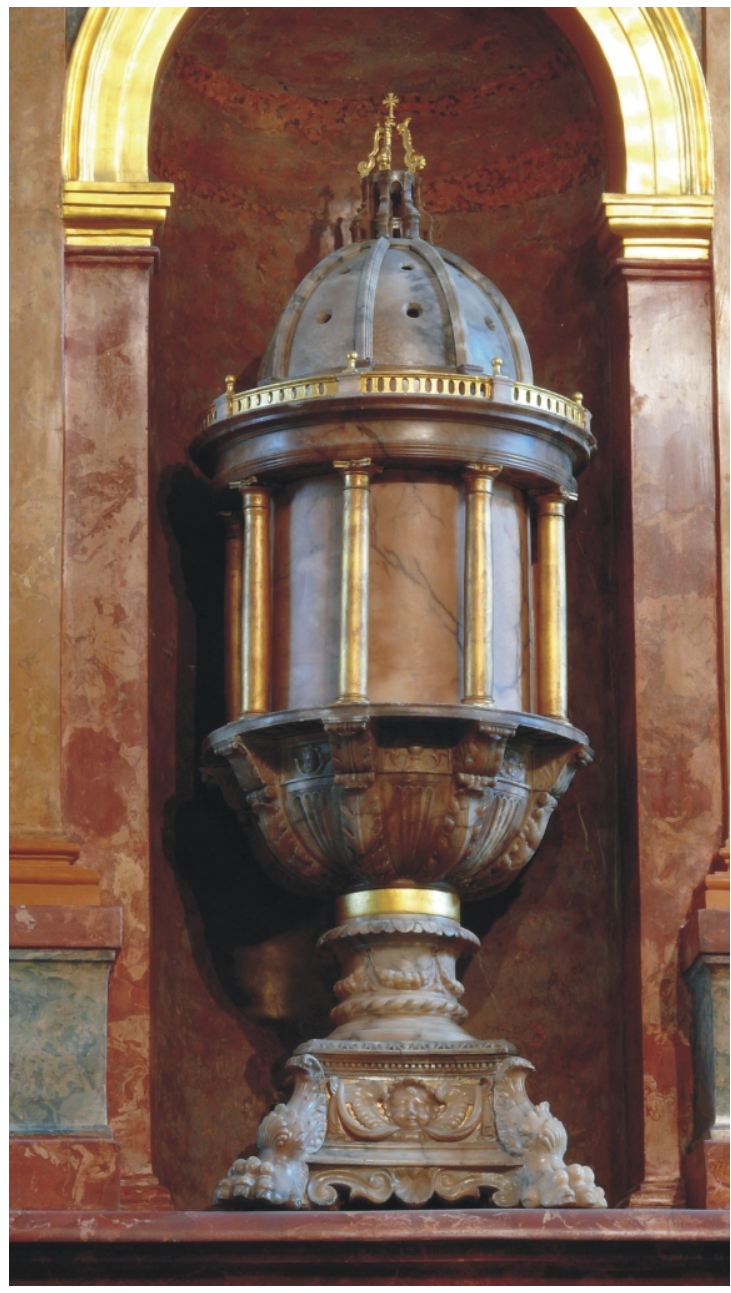

Fig. 6. Church of Our Lady Assumed into Heaven - St. Mary's Church, Main Market, Kraków; tempietto sacrarium; alabaster of Vasiuchyn or Zhuravno, sculptor: Giovanni Maria Mosca called Padovano (attrib.)

Photo by M. Wardzyński

Stopano, a Kraków master and at the time the major leaseholder of the quarries of the black "marble" at Dębnik, took part as a major stonemason (Wardzyński, 2012a, b).

The Chapel of the Holiest Virgin Mary's Immaculate Conception. The beginnings of this chapel (also called the Vasa Dynasty Chapel) reach back to the first half of the 13th century and a foundation of Jan Prandota, a Kraków bishop, who declared it the burial place of St. Stanislaus' remains and the place of show of his relics. After 1598, King Sigismund III Vasa selected this chapel as the place of burial for his own family. His plans were completed during the reigns of Władysław IV and Jan II Kazimierz, who financed in the years 1644-1645 and 1665-1669 the creation of a new burial chamber (crypt) and a total restructuring of the chapel into a sophisticated Baroque travesty of the adjacent Sigismund Chapel. The materials applied as the stone facing of the chapel interior include Dębnik limestone, vein calcite of Paczółtowice ("Różanka") and the Chęciny limestones of two types (Bolechowice and Zygmuntówka). They were supplied mainly by Adam Gabrysiowicz vel Negowicz (first mentioned in 1651; deceased 1681), a leaseholder of the quarries at Dębnik, whereas documents of the Cathedral Chapter link the ornamental elements with a renowned Kraków master, cooperating also with the Dębnik mason cen- tre, the woodcarver and stonemason Marcin Bielawski coming from the Podolia region (mentioned in 1654-1689; Rożek, 1980; Wardzyński, 2012b). Bielawski was an author of superbly sculpted ornamental decorations, some in Ruthenian alabaster: they flank from the bottom and the top niches in the side walls, mannerist small heads of angels with fruit bunches hanging on vernacles, and oval cartouches with cartilage-auricular frames and zoomorphic masks. They belong to the latest such works identified throughout the whole Commonwealth of Poland and Lithuania after the damaging of the Podolia quarries by Chmielnicki's Cossacks.

\section{THE ST. MARY'S ASSUMPTION BASILICA}

The parish church of Kraków was the most important place of religious life and of interment of town patricians and other higher-positioned burghers. The imposing ciborium in St. Mary's church is the earliest work in Kraków in which a semi-transparent, honey-yellow alabaster from the Vasiuchyn or Zhuravno deposits was used. It was commissioned on 2nd July 1551 by Andreas Marstell and Georg Pipan and executed by Giovanni Maria Mosca, called Padovano (Kozakiewiczowa, 1983; Fig. 6), in the years 1552-1554 (according to Kozakiewiczowa, 1983; Markham-Schulz, 1998; Wardzyński, 2010a), or 1551-1554 (according to Markham-Schulz, 1998), or 1551-1553 (according to Wardzyński, 2010a). The sculptor was paid 5 zloty for 14 weeks of work from 2nd July to 8th October 1552 . The work was finally completed in July 1554 (Markham-Schulz, 1998). More recent sources attribute the alabaster tabernacle to Santi Gucci Fiorentiono (ca. 1530-1600), the court artist of Sigismund II Augustus (Markham-Schulz, 1998). The material used was either to imitate the white Carrara marble or to approximate, considering the colour and texture, the alabaster of Volterra commonly used to decorate church interiors (Wardzyński, 2010a, b). Another alabaster work by Gucci Fiorentino is the stalls of the Montelupi family completed before 1568 (Fischinger, 1969; Kozakiewiczowa, 1984; Kowalczyk, 1987; Daranowska-Łukaszewska, 1997; Wardzyński, 2010a).

Except for the previously mentioned outstanding works from the second half of the 16th century inside the church, and on its façades, nine other extant epitaph plaques can be seen. Their bas-relief figures or structural parts were cut mainly from the honey-yellow alabaster of Vasiuchyn. The oldest is the monument of Hans Kristein Cerasin (deceased 1561), followed by the plaques of Andreas Rottermundt (deceased 1593) and Barbara Kuczkowska née Salamon (deceased 1603), the last a work of Johann Sigmund (Giovanni de Simon vel de Simonis) of Tirol; all three have inscription plaques with an alabaster background. Active in the city in the 1580s and 1590s, Sigmund obtained the dark olive alabaster from Kukilnyky at least two times. He used it to make details and low-relief figural plaques of two tombs: that of Marcin Leśniowolski the Elder (died in 1593) and of Piotr Kostka (died in 1595), a bishop of Chełmża (German: Culmsee) in Royal Prussia who was buried in the cathedral there.

Alabaster was used to curve the field of the of the Cellaris family coat of arms, which was placed in a cartouche (prior to 1616 ) in the portal of the sacristy. The group of works from the 1630 s to the 1650 s belong to the Kraków and Dębnik artistic circles, headed then by Sebastiano Sala and Bartholomeo Stopano respectively. The former master used Vasiuchyn alabaster to create the figures of Our Lady with the Child, encircled by clouds, and the kneeling and adoring figures of Christoph Szober (made in 1634), Stanisław Szembek (died in 1638) and Anne Szembek née Amenda in the Chapel of Our Lady of Loretto, and also in the monuments of Cyrus Landmann (died in 
1652) and the Derjakubowicz family (probably a reused monument from ca the mid-17th century, transformed later ca. 1763). The last work in which Vasiuchyn alabaster was applied (ca. 1679 ) is the tomb of the Pernus family in the southern porch, where small fragments of deficit alabaster were used in main elements of the coat of arms (Rożek, 1977).

In the western wall of the nearby St. Barbara's church the alabaster epitaph plaque of Georg Pipan, set to the right of the entrance, displays vertical streaks of crystalline gypsum (Rajchel, 2005).

\section{THE CHURCH OF THE HOLY TRINITY AND THE MONASTERY OF THE DOMINICAN ORDER}

The next selected architectural site rich in historic alabaster stoneworks is the brick-and-stone church of the Dominican fathers, consecrated in 1223. Most of the tombs and epitaph plaques had been located inside the basilica, distributed mainly on the walls of side naves and chapels, prior to a fire in 1850. After this disaster and the comprehensive rebuilding and regothicization that followed (1853-1854 and 1856-1884), all of them were moved to the priory's cloister: some of the damaged pieces were replaced with elements collected from irreversibly destroyed and some others were deposited in a lapidary on the southern wall of the passage leading to the cloister gate. Except for the already mentioned works of Canavesi (epitaph plaque of the Koryciński family dated ca. 1560) and Jan Michałowicz (Gabriel's of Szadek plaque, 1563), the alabasters from Vasiuchyn or Zhuravno were set in the backgrounds of the inscription tablets of the modest epitaph plaques of two Italians, Christophoro Tenbra and Sebastiano Lombabardi (deceased 1580). The most interesting is the work of a previously unrecognized sculptor. It is a small, overhung, late Renaissance monument of an undetermined noblewoman, dated to the fourth quarter of the 17th century, whose ornamental crowning connects it with an older, Dutch-type cartouche with the Nowina coat of arms. The cartouche was made in the 1560 s or the 1570 s and came from the circle of Jan Michałowicz of Urzędów. Worthy of attention is a three-dimensional figure of a female child referring to the works of Johann Sigmund aka de Simonis, executed precisely from a small block of a patterned alabaster with veins of reddish hematite. Another example of a Renaissance spolium (i.e., a reused part of an architectonic or sculpting work) is the epitaph plaque of Krzysztof Mocarski (deceased 1579), onto which (following the 1850 fire) a pair of voluted "ears" ornamented with acanthus leaves, sculpted from Kukilnyky alabaster, was attached. In the first half of the 17th century, alabaster from Vasiuchyn was used in the unusually large monuments of Baltazar Balcerowicz (deceased 1627) and Paweł Piotr Tryzna (deceased 1639). In the former alabaster is the material used in an oval portrait tondo, in the latter the materials of an extremely ornamental mantling of a coat of arms and a vernacle suspended in three points.

The Chapel of St. Hyacinth. The chapel, which is located over the northern nave (i.e., on the upper floor) of the church, was built in the mid-16th century and was restructured several times (Łoziński, 1970). In the years 1581-1583 the late Renaissance tomb of St. Hyacinth and his reliquary altar were constructed, either by a pupil of Jan Michałowicz, Jan Biały of Kraków, or by Heinrich Horst, using the red marble from either Upper Hungary or Transylvania and several different varieties of alabaster (Sinko-Popielowa, 1946; Mańkowski, 1948). The original construction, made of stromatolitic gypsum encrusted with alabasters from Vasiuchyn and Zhuravno, consisted of a high, rectangular, two-stage socle with an altar. In accordance with French and Dutch transi traditions, a massive canopy with a quasi-cupola crowning that rested on six columns in the enriched Doric order was raised over the altar. The decorations, cut from Zhuravno and Vasiuchyn alabasters, were composed mainly of Scheiffwerk-Rollwerk and grotesque motifs. A matching, unusually rich figural composition included several dozen honey-yellow, semi-transparent figures of Polish and Dominican saints and representations of theological, angelical and cardinal virtues which surrounded two major figures of St. Hyacinth: one lying dead on the bier and the other kneeling in a pose of adoration at the front of the crucifix on the cupola. The tomb survived until 1623 and was then disassembled due to its excessive weight that threatened the carrying capacity of the vaults of a nave span and of an old sacristy below. As a result, in 1629 the Dominican fathers replaced the original altar with another, lighter structure designed by the brothers Andrea and Antonio Castelli (Łoziński, 1970; Karpowicz, 2002). Parts of the old altar were transferred to the church of St. Idzi (Saint Gilles the Hermit; Grodzka Street), overseen by the same convent (Fig. 7). The reutilized parts were used to construct two segments of the stalls in the chancery and two portals: one for the inner, southern entrance and the other for the entrance to the sacristy; both were decorated with stone details and figures, arranged randomly (Sinko-Popielowa, 1946; Mańkowski, 1948;

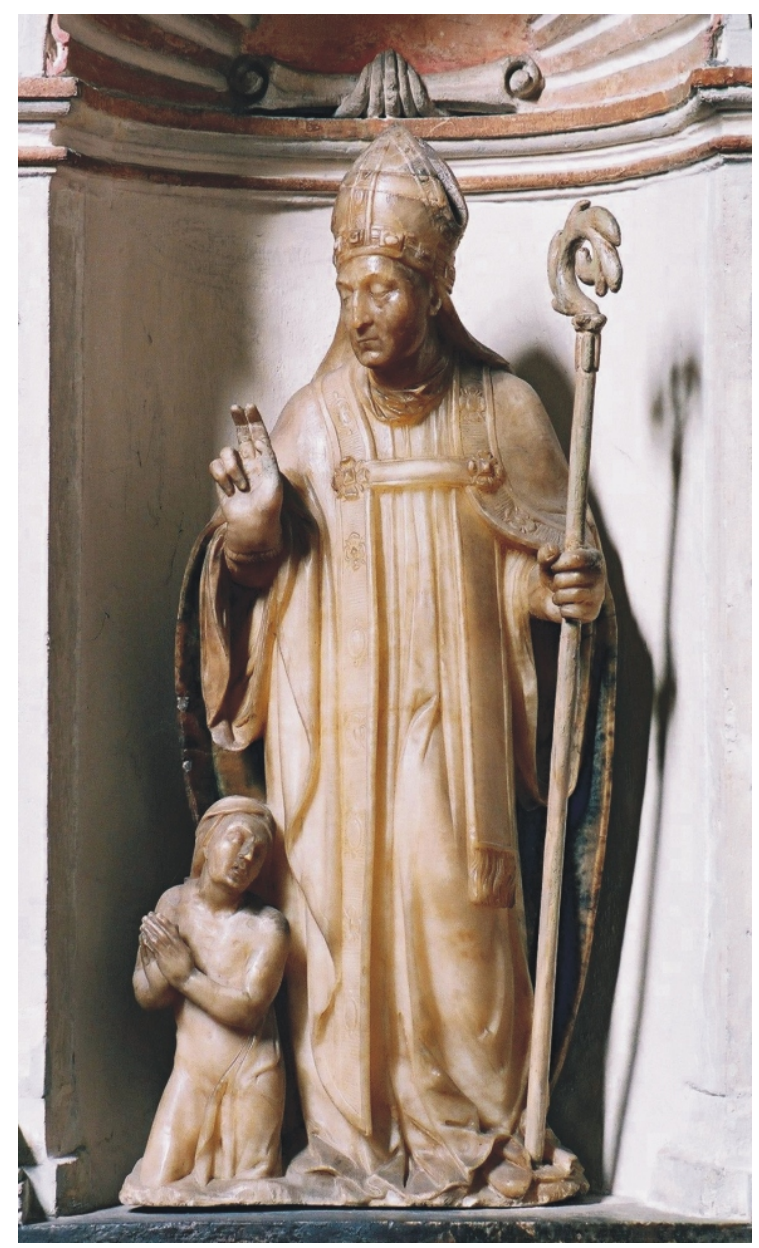

Fig. 7. Church of St. Idzi (St. Giles), Grodzka Street, Kraków; the stalls: the figure of St. Stanislaus transferred from the non-extant reliquary altar of St. Jacek (Hyacinth) in his chapel-sanctuary in the basilica of Dominican fathers; alabaster of Vasiuchyn or Zhuravno, sculptor: Jan Biały or Heinrich Horst

Photo by M. Wardzyński 
Wardzyński, 2010a). In the Dominican cloister itself only three alabaster sculptures from the old altar remained, all stored in the strong-room. A sculpture of Our Lady is one of them: she rests on a throne added in the second half of the 17th century. The other two are angels cut from honey-yellow alabaster, which were probably set in the crowning of the original St. Hyacinth's tomb; such a position is suggested by the angels' postures and gestures: one holds an hourglass, and the other has been presented with a sphere with one hand directed towards the heavens (Nowak and Turdza, 2007).

The Chapel of the St. Catherine of Siena. The monumental Baroque chapel of the St. Catherine of Siena, known as the Zbaraski family chapel, was erected in 1627-1633 following a commission of Duke Jerzy Zbaraski, a castellan of Kraków (deceased 1631). It was designed by royal architect Matteo Castello, and the interior decorated by his nephews the Castelli brothers, Andrea and Antonio (Tatarkiewicz, 1953; Łoziński, 1970; Karpowicz, 2002; Chrzanowski, 2008). Its stone décor is dominated by "black" Dębnik limestone with elements of pinkish Paczółtowice vein calcite; of particular interest are six huge columns of the portal, made of "Zygmuntówka" conglomerate from the Holy Cross Mts. (Rajchel, 2005). A tomb of the founder's brother, Duke Krzysztof Zbaraski (deceased 1627), is situated on the left side; its design corresponds to the Renaissance sepulchral tradition introduced by Bartolomeo Berrecci in 1530 in the tomb of King Sigismund I the Old in the Wawel Sigismund Chapel. A full figure of the deceased rests on his back, his head supported by an artistically bent mattress. He wears typical 16th-century full plate armour, with greaves and steel sabatons. The sculptor precisely replicated the real features of the duke's face and all the details of the armour's plates and rivets, but introduced an ornament on the tasset protecting the knight's upper legs. Berrecci used a decorating technique characteristic to Kraków sculptures of his period based on using a chisel to make deep notches on previously polished surfaces (Karpowicz, 2002).

The tomb of the chapel founder, Duke Jerzy Zbaraski (deceased 1631), faces that of his brother and is also patterned in the likeness of the tomb of King Sigismund I the Old in Wawel Chapel. The sculptor replicated the posture, the position of its right arm bent at the elbow, and the bend of its head resting on knight gauntlets, of the 100 year old figure. In his left hand, Duke Jerzy holds a commander's baton not extant till today, and his right hand lies on a partly preserved ducal coronet. Some damage can also be seen in the Duke's left leg, where the foot is missing (Karpowicz, 2002). Both figures of the Zbaraski brothers were sculpted in alabaster from Podolia: the honey-yellow rock, with streaks of lighter spots in places.

THE BASILICA OF ST. FRANCIS OF ASSISI AND THE MONASTERY OF THE FRANCISCAN ORDER

Another historical church in Kraków that uses alabaster from the Podolia region in its interior décor is the church of the Franciscan fathers, probably consecrated in 1269. The most interesting alabaster decoration can be found in the chapel of blessed Salome. This originally Gothic chapel dates back to the 15th century (one of the oldest chapels of the church) and was rebuilt in 1655 (Fig. 8; Rożek, 2010a).

Podolian alabaster is present in the two-stage altar sculpted in the year 1640 or 1670 and is accompanied by two other stones, the "black" limestone from Dębnik and a Carboniferous limestone. In the centre there is a painting showing a vision of blessed Salome (lived ca. 1211-1268), framed by rectangular pillars made from Dębnik limestone, with extensively carved capitals, simple bases and ornaments cut from the white,

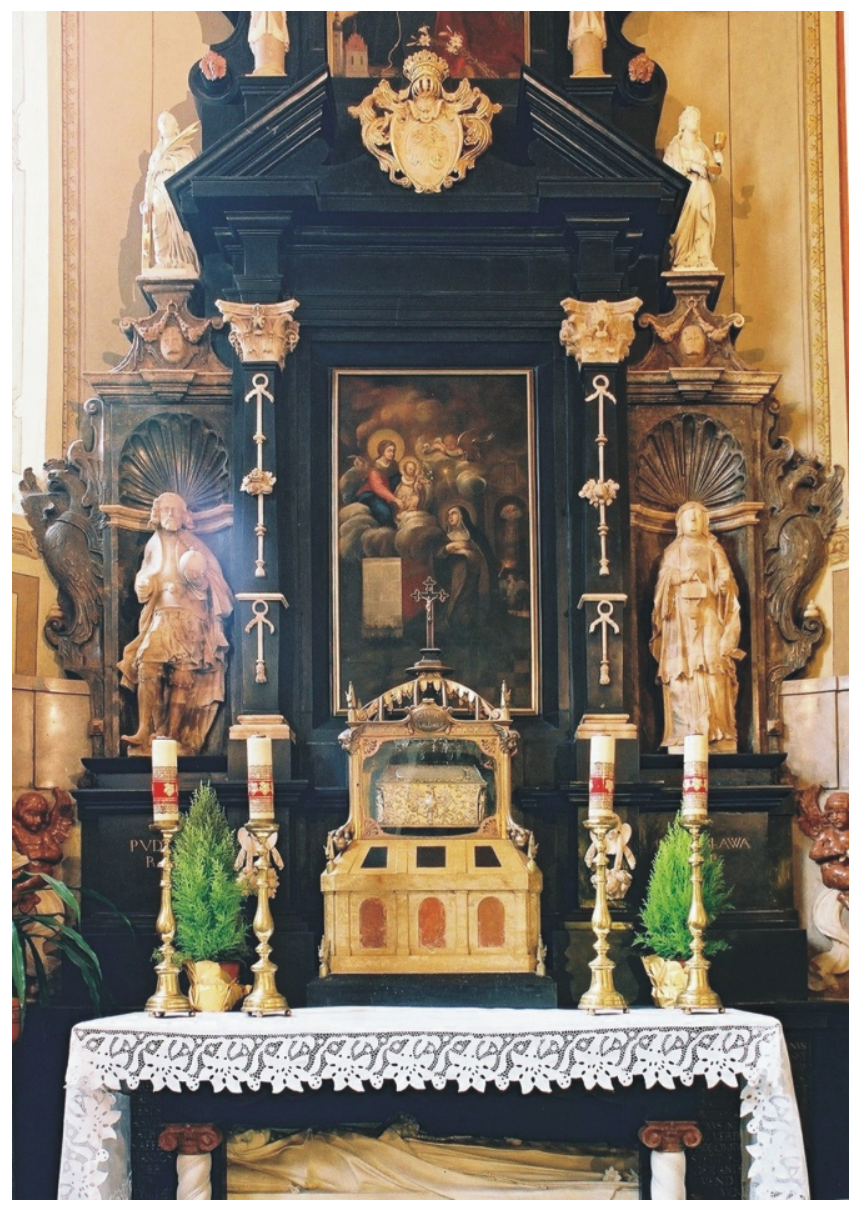

Fig. 8. Church of the Franciscan fathers, Franciszkańska Street, Kraków; the altar in the Chapel of Blessed Salome

Photo by M. Wardzyński

slightly yellow alabaster from Vasiuchyn. On its left, in a niche, there is a figure of Duke Boleslaus $V$ the Shy, who holds in his left hand the royal globe and in his right a scepter, the latter of which is now missing, but was still present in an old photograph of Jerzy Langda (Bochnak and Samek, 1971). On the opposite side stands a figure of the Duke's mother, Princess Grzymisława, who holds in her right hand a document with an impressive seal; probably the foundation charter of Kraków in 1257 (Bochnak and Samek, 1971); she must have also held something in her left hand, but it is now empty (Fig. 9). Both figures were cut in white, slightly yellow alabaster from Vasiuchyn, while the walls of the niches are lined with dark olive alabaster from Kukilnyky. The remaining marble and alabaster parts, ornaments and statues of the retable all assembled in its upper stage, crowning and extended earings, were sculpted in the neo-mannerist style when the chapel was enlarged ca. 1900. The niches have conchoidal, ribbed vaults terminated with a cornice made of a yellowish, stromatolitic alabaster. Above, surrounded by fruit festoons, there is an oval shield with a cross fitted into a horseshoe. Outer margins of the niches are flanked by sculptures of crowned eagles with asymmetrically spread wings, carved in dark olive alabaster from Kukilnyky. Below, there are two winged, small angels of the calcare ammonitico rosso with garlands of flowers, fruits and ribbons made of white semi-transparent alabaster from Zhuravno, and a volute cut in a Carboniferous limestone with a blooming sunflower head crowned with a cross, the latter two works carved in the same alabaster as the garlands mentioned above. 

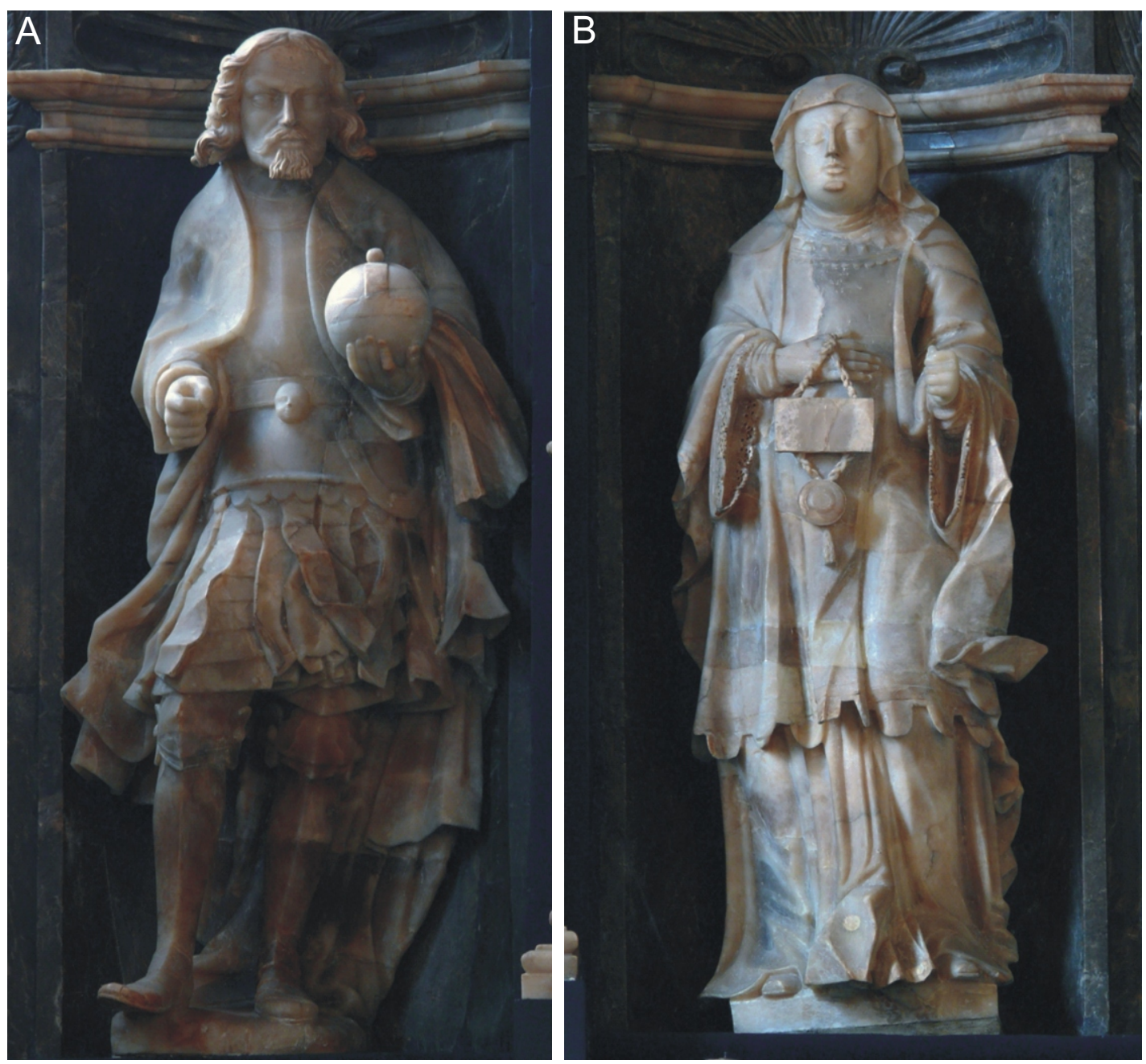

Fig. 9. Church of the Franciscan fathers, Franciszkańska Street, Kraków; the Chapel of blessed Salome: A the statues of Duke Boleslaus V the Shy and B - his mother, Princess Grzymisława - alabaster of Vasiuchyn (?), the background of the niche and stylized eagles - alabaster of Kukilnyky (?), sculptor unknown

Photo by M. Wardzyński

Higher up in the altar there is a gilded, probably alabaster cartouche, the figures of St. Catherine and St. Barbara, and in its upper part the painting of St. Kinga (Kunegunda), Prince Boleslaus' sister, flanked by marble(?), spiral columns with ornaments made of white alabaster in their lower sections. The very top of the altar is crowned with a cross made from calcare ammonitico rosso, and on the sides there are two small angels and fruit ornaments, all of them cut from white alabaster. Under the mensa rests a figure of blessed Salome, and on the mensa her Baroque reliquary, ornamented with bas-reliefs of winged small angels with flower garlands; all these sculptures are made from the semi-transparent alabaster from Zhuravno.

\section{OTHER EXAMPLES FROM THE EARLY MODERN ERA}

Worthy of mention are other alabaster objects selected from a list of the most interesting ones in the historical sacred sites of Kraków. Probably the oldest of them is a mannerist small domestic altar showing the scene of Crucifixion (ca. 1600-1630) which was made in a northern style with the semi-transparent Vasiuchyn alabaster, stored in the convent of the Sisters of St. Clara.
At the end of the 18th century it was renovated and topped with a Rococo-Classical crowning (Bochnak and Samek, 1971). The most splendid object may be a wall reliquary altar of St. Stanislaus of Kazimierz (deceased 1489), made in 1630-1632 by the Castelli brothers (Andrea and Antonio); it is located in the northern aisle of the parish church of Corpus Christi that belonged to the Canons Regular of the Lateran Congregation from the adjoining monastery (Tyrowicz, 1977; Karpowicz, 2002; Dettloff, 2012). The main field of the altar is occupied by a bas-relief, half-figure presentation of Our Lady with the Child surrounded by clouds, cut in the yellowish, semi-transparent Zhuravno alabaster (Rajchel, 2005; Fig. 10). The bas-relief is identical to that placed in the centre of the composition of Bishop Andrzej Lipski's tomb in the Wawel Cathedral.

In the same period were created twinned, sculptural epitaph plaques of Wojciech Chodorowicz (deceased 1628) and Giacomo Famuti of Lucca (deceased 1641), in which alabaster from Wasiuczyn was used in pairs of ornamented espagnolettes created in an undetermined workshop in either Chęciny or Kraków. Originally assigned to the Church of Discalced Carmelites of St. Michael Archangel and St. Joseph in Poselska Street, after demolishing the church they found their way, alongside other marble decorative elements, to the porch of the 
Church of the Bernardine fathers in the Stradom quarter in 1867 (Rejduch-Samkowa and Samek, 1987). As a result of this relocation, a highly ranked side retable of blessed Salome of 1639 , initially assigned to a small church of pardon on Grodzisko Hill near Skała, was installed in the church of the sisters of St. Clara in Kraków (i.e., the Church of St. Andrew, Grodzka Street). The espagnolettes, cut in the honey-yellow, semi-transparent alabaster from Vasiuchyn (Bochnak and Samek, 1971), and patterned after analogue ornaments in tombs in Gniezno and Sieraków imply that Sebastian Sala was the possible designer and sculptor. The same workshop may have made alabaster, small winged heads of angels in the keys of "earing" portals in the transept arms and two first chapel pairs of the Jesuit church of St. Peter and St. Paul, which were made in stages between ca. 1630 and 1690 (Rejduch-Samkowa and Samek, 1987).

\section{THE ST. VINCENT DE PAUL CHURCH OF THE MISSIONARY CONGREGATION}

The brick Church of the Congregation of Missionaries of St. Vincent de Paul is located in St. Philip Street, opposite the Old Clepardia Place (an open-air market). The church was built in

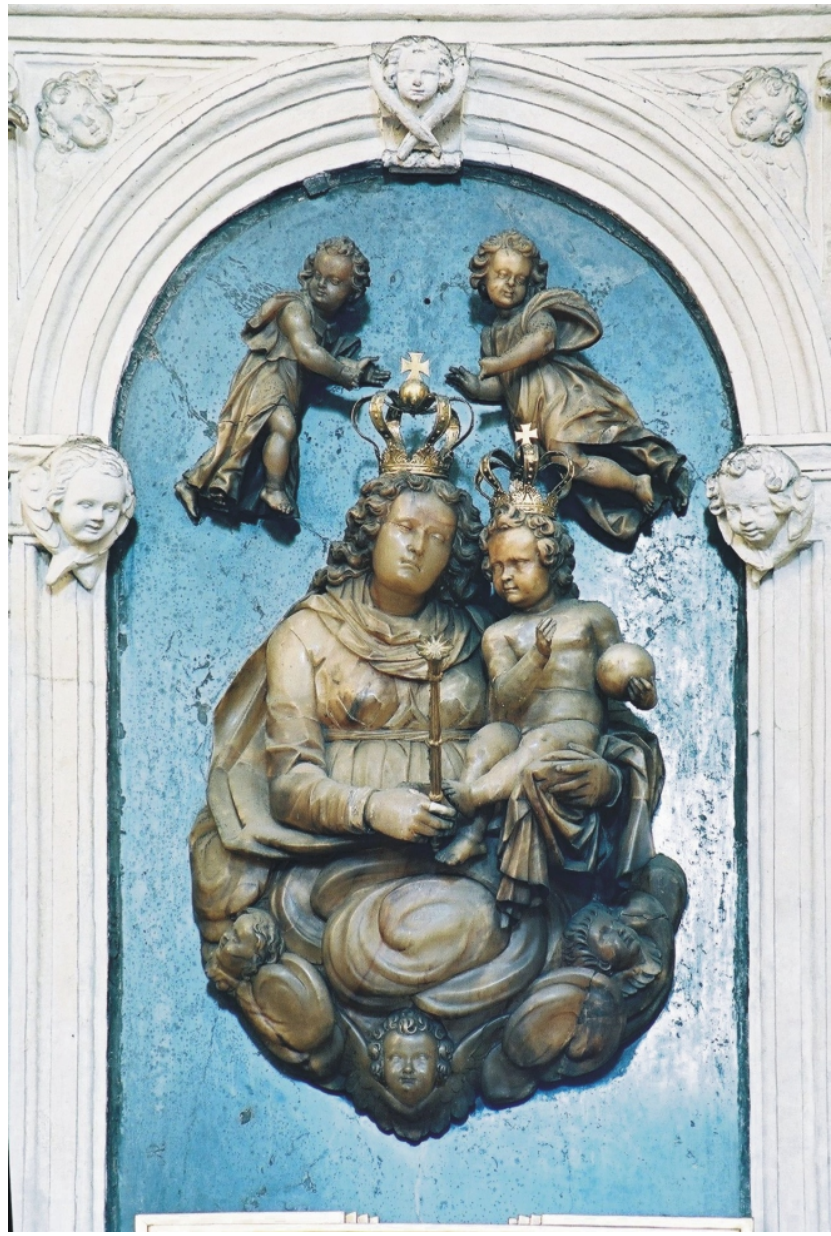

Fig. 10. Church of Corpus Christi, Wolnica Place, Kazimierz district, Kraków; the reliquary altar of St. Stanislaus of Kazimierz: the statue of Our Lady and the Child; alabaster of Zhuravno, sculptors: Andrea and Antonio Castelli

Photo by M. Wardzyński two stages, in 1875-1877 following a design by Filip Pokutyński, and in 1911-1912 following further plans from Jan Sas-Zubrzycki. Alabaster-made decorations can be found in the main altar and in a side altar, the altar of the Mother of God of Lourdes, carved in Podolian alabaster in 1934-1936. In the years 1956-1957 two new altars were added using Pińczów limestone and marbles from the Lower Silesia: one with a figure of St. Vincent de Paul and also of St. Anthony and St. Joseph; the other of the Passion of Christ, with the miraculous Baroque painting of Christ Crucifixion brought to Kraków after World War II from Myliatyn, near Lviv.

The main altar, with wooden figures of the Sacred Heart of Jesus, St. Peter and St. Paul, was constructed in 1935-1936, designed by Franciszek Mączyński (Rożek, 2010a), using alabaster from Podolia (Fig. 11). The antependium is composed of slabs of white alabaster, from Zhuravno, with subtle, darker streaks and dark ash-grey, highly brecciated alabaster, also from Zhuravno; of the latter were also carved two massive, spiral columns supporting the mensa. The centre of the antependium is occupied by an unusually beautiful bas-relief sculpture in the art déco style, cut from pure white alabaster from Zhuravno, with an inner, thick frame made of the same stone and an outer frame from brecciated alabaster. The sculpture is

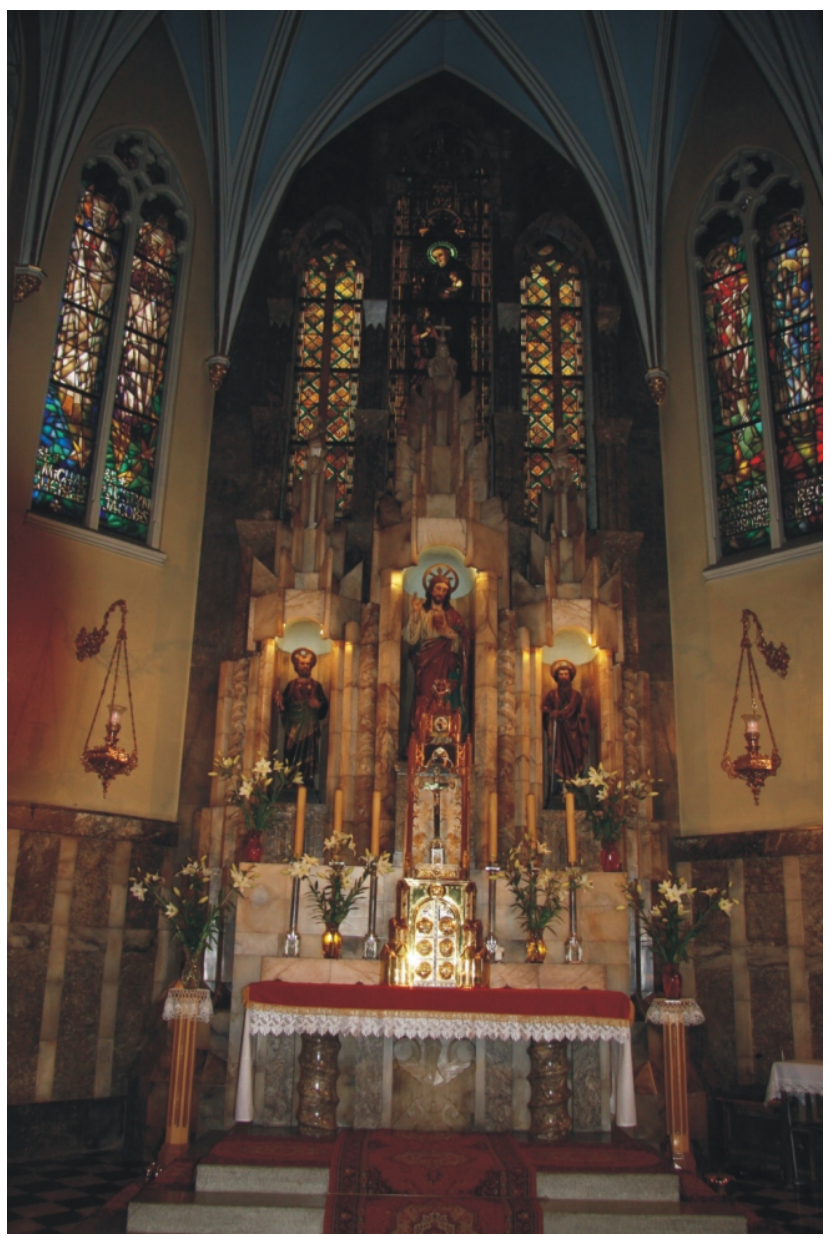

Fig. 11. Church of the Congregation of Missionaries of St. Vincent de Paul, St. Philip Street, Kraków; the main altar designed by F. Mączyński; alabaster of Zhuravno, sculptor unknown

Photo by J. Rajchel 
of a stylized pelican with spread wings that feeds two nestlings with blood from its own chest. It is a symbolic Christian scene: the pelican reflects either the universal church while the nestling reflects its believers, or it symbolizes Jesus Christ redeeming us through his death, or it refers to the idea of resurrection (Rożek, 2010b; Fig. 12). Such a motif is often used in historical, early modern, and contemporary Polish ecclesiastical art, e.g., it can be seen in a mosaic in the Lichen sanctuary.

The mensa is a thick slab of white alabaster with a few, darker streaks; the retable is divided into three conchoidal niches topped with stalactite-like turrets. The lower part of the retable and the walls of the niches were cut from white alabaster from Zhuravno with ivory-coloured streaks and irregular veins. This altar part was decorated with vertical, deeply sculpted zones with plants stylized in geometric patterns. Each of the niches is covered with a spiral turret with a geometrically stylized finial, while the middle one also features a sphere, topped with a cross. The background of the niches, which form a retable, is lined with dark, ash-grey, brecciated alabaster, and terminated by four freestanding pillars with decorative corbels. They are linked to an openwork screening of three stained glasses in the back wall of the church; the screen is made from yellowish, brecciated alabaster. The altar is flanked by massive, narrowing step-wise, deeply profiled pillars of a white to slightly yellowish semi-transparent alabaster which rest on expanded bases. The altar is located within an apse, the wall of which has a low plinth made from a spotty, brownish alabaster, and in a higher part a lining of brecciated, dark ash-grey alabaster from Zhuravno, and it is terminated by a cornice cut of the same alabaster as the lining; the lining itself is intersected by vertical belts of a light ash-grey alabaster. The portal of the sacristy door is made of the brecciated alabaster - the same stone as in the lining.

The nave and the chancel are separated by a massive, stone balustrade of simple construction, with geometric divisions and slant small beams in its sections. The whole balustrade was cut from semi-transparent, mostly white but in places yellowish, streaky and spotty alabaster from Zhuravno (in some fragments the stone is brecciated) with ornaments made of a spotty, brownish alabaster.

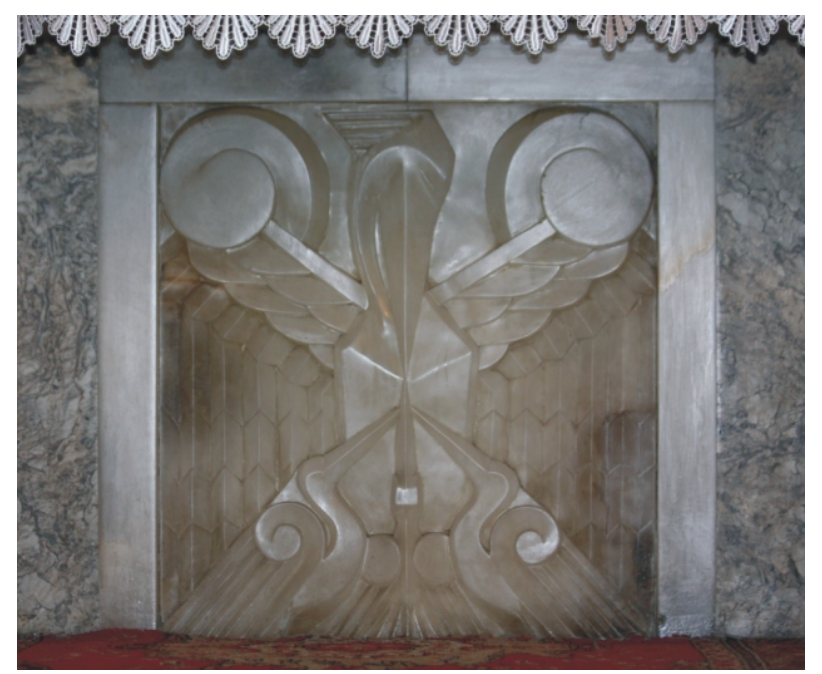

Fig. 12. Church of the Congregation of Missionaries of St. Vincent de Paul, St. Philip Street, Kraków; the main altar: the bas-relief of a stylized pelican that feeds two nestlings with the blood from its own chest; white alabaster of Zhuravno, sculptor unknown
The Chapel of the Mother of God of Lourdes. The chapel was designed by Franciszek Mączyński and constructed during the church's expansion in the years 1911-1912 in the form of a wide, oval apse. A balustrade made of the same material and following the same design as that of the main altar separates it from the nave. The alabaster altar in the chapel adjoins the wall and was constructed in 1934-1936 - its consecration took place on 15th November, 1936. It is made from several varieties of alabaster and patterned into a symbolic Lourdes grotto (Fig. 13).

The retable is made from rectangular slabs of white Zhuravno alabaster with subtle dark streaks. Its upper part forms a niche with a statue made in 1889, presenting Our Lady of Lourdes - the Mother of God, and is lined with slabs of the same alabaster as the retable. The niche is screened by a row of white, semi-transparent alabaster "stalactites" of varying length; its colour approximates that of the rock applied in the niche. The figure stands on a pyramidal pedestal with gilded alabaster finials; Our Lady has a triple alabaster crown under her feet (the same rock as mentioned above). The statue is flanked by two alabaster flowerpots or candlesticks of a white alabaster with subtle veins. The whole altar is framed by an arc going down to the chapel floor; the arc is made of dark ash-grey, brecciated alabaster from Zhuravno, the same rock as that from the main altar.

The walls of the apse have a low plinth made of a single row of rectangular slabs of brownish alabaster, overlaid with slabs of white alabaster from Zhuravno with subtle veining. Around the whole perimeter of the apse are distributed votive cabinets, separated from each other by rectangular slabs of white alabas-

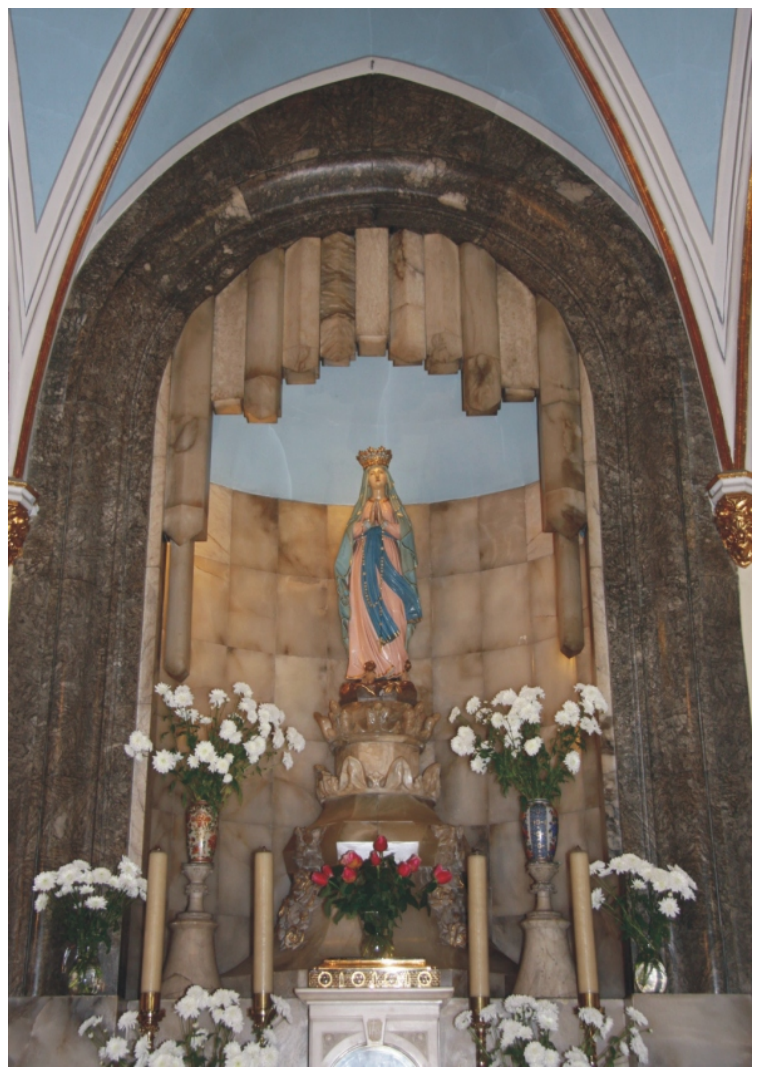

Fig. 13. Church of the Congregation of Missionaries of St. Vincent de Paul, St. Philip Street, Kraków; the Chapel of Our Lady of Lourdes designed by F. Maczyński; alabaster of Zhuravno, sculptor unknown 
ter with a monogram of Our Lady. Over the cabinets run a narrow belt of dark ash-grey, brecciated alabaster; this rock was also used to encase heaters set into the walls.

\section{THE CHURCH AND MONASTERY OF DISCALCED CARMELITES}

An excellent example of the applications and benefits of using alabaster, considered as a sculpting material in sacral arts from 1918-1939, is the décor of the Church of Discalced Carmelites in Rakowicka Street. It was constructed in stages: in 1907-1910 following plans by Tadeusz Stryjeński, and in 1929-1932 following a design by Franciszek Mączyński (Rożek, 2010a). Lviv "marble" was used to sculpt the main altar, side altars, pulpit and a whole range of architectonic details. Most of alabaster sculptures of the church were cut by J. Horodyska (Smirnow, 2005).

The main altar, with the painting of Immaculate Virgin Mary that is a copy of Bartolome Murillo's Madonna (Głos Karmelu, 1932), was made using two Zhuravno alabaster varieties (white and grey), illuminated from inside. It was prepared in Żurawno, the Czartoryski ducal Alabaster Quarries and Workshop of Alabaster Goods, and designed by J. Szostakiewicz, Eng. (Cloister's Chronicle - "Kronika Klasztoru oo. Karmelitów Bosych w Krakowie" [in Polish], without publication year and page numbers; Głos Karmelu, 1932; Wiśniewska, 1997), and assembled in Kraków under the supervision of Józef Trawersa of Lviv (Fig. 14).

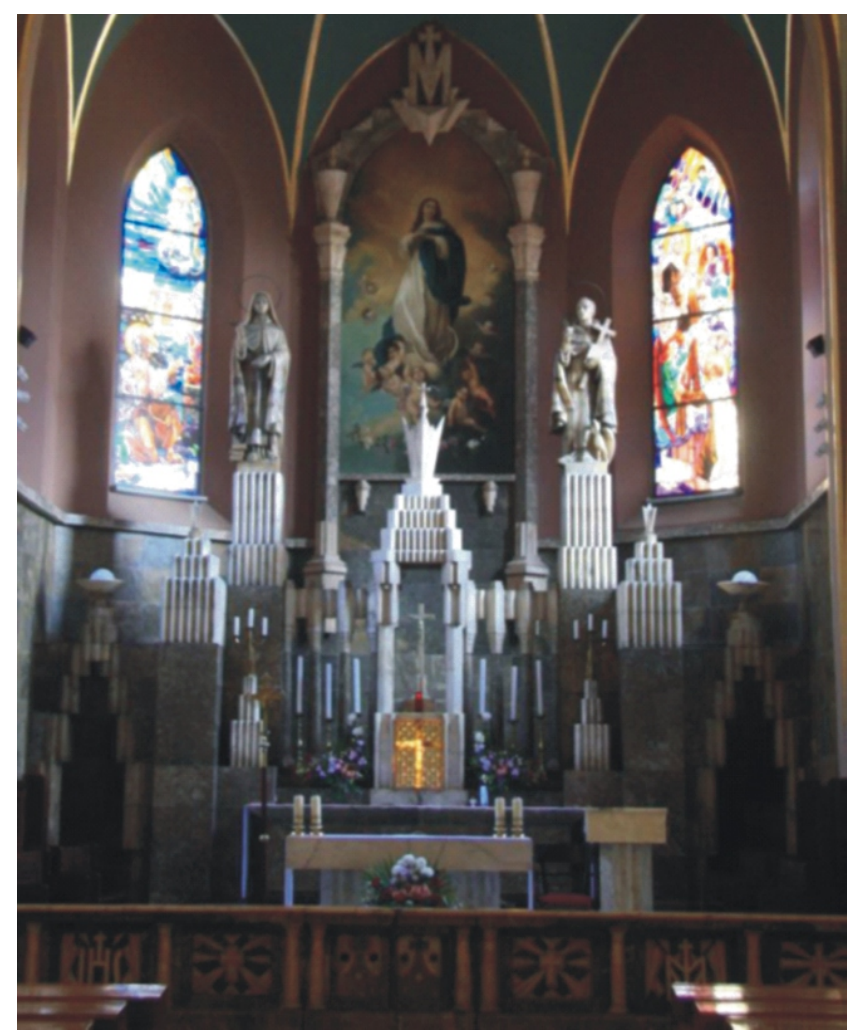

Fig. 14. Church of Discalced Carmelites, Rakowicka Street, Kraków; the main altar designed by Józef Szostakiewicz; alabaster of Zhuravno, sculptress: Jadwiga Horodyska

Photo by J. Rajchel
Two alabaster posts flank the painting and their sculpted capitals support white illumination lamps. The whole frame is crowned by a monogram with the name of St. Mary, lit from behind. The altar tabletop (mensa), antependium and predella were made from grey, strongly veined alabaster, while the tabernacle, with a pedestal that displayed the Holy Sacrament, was made using white alabaster. Four small pillars support a fluted white cupola with a crown that carries a cross on top. The grey-alabaster retable is flanked by the figures of the Carmelite order reformers: Saint Thérèse of Jesus (St. Thérèse of Ávila) and St. John of the Cross, positioned on high pedestals made of white alabaster. The statues were cut at Zhuravno from white alabaster, intersected in places by thin veins of the grey variety by the Italian sculptor Bertini (Głos Karmelu, 1932). St. John of the Cross is shown as a Doctor of the Church, with a pen in one hand and a thick volume together with a cross in the other. An eagle taking flight at his feet ("aquila metaphysicans") symbolizes an ascent to God (Fig. 15). Saint Mother Teresa holds a pen in her right hand, and in her left she supports one of many books she authored, while the remaining books rest at her feet (Wiśniewska, 1997).

The altar is placed against the walls next to two passages topped with illuminated bowl-shaped vases. Side plinths with

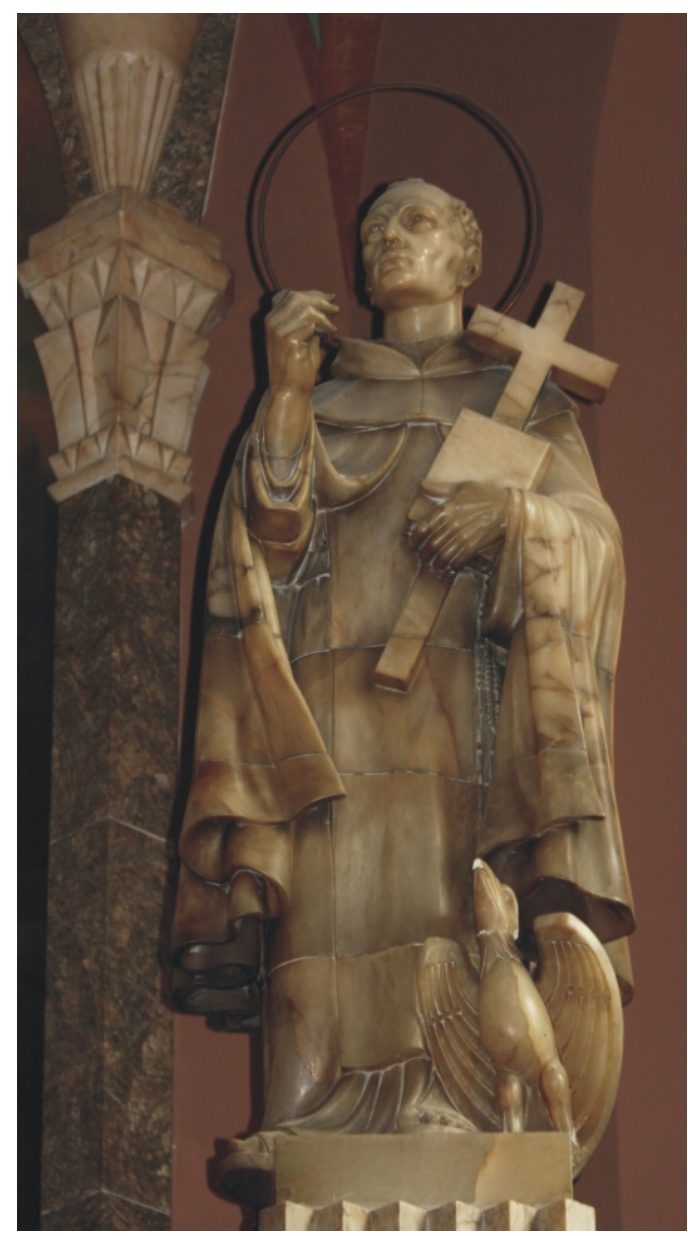

Fig. 15. Church of Discalced Carmelites, Rakowicka Street, Kraków; the main altar: the statue of St. John of the Cross; alabaster of Zhuravno, sculptor: Bertini

Photo by J. Rajchel 
miniatures of crowns are linked to the tabernacle with a row of small columns that make an openwork predella. White and grey alabasters with beautiful incrustations were used to construct the balustrade separating the chancel from the nave. The altar was consecrated by a metropolitan of Kraków, Archbishop Adam Stefan Sapieha, on 13th December 1932 (Głos Karmelu, 1932).

The altars in the aisles dedicated to St. Thérèse of the Child Jesus and St. Joseph were cut in white and brown spotted alabasters, also according to J. Szostakiewicz's design (Cloister's Chronicle; Głos Karmelu, 1932). The first of them is an architectonic one-axial and one-stage crowned altar. Its mensa is supported by kneeling angels, which symbolize humility and love, cut by Bertini in white alabaster (Fig. 16). Between the two, in the niche of the antependium, rests the figure of St. Thérèse, cut by J. Horodyska and patterned after the sarcophagus of St. Thérèse in the Lisieux basilica. Into a high plinth was incorporated the tabernacle, ornamented with plant motifs: grain spikes and grape bunches (Smirnow, 2005). In the retable there is a painting of St. Thérèse. The retable is flanked by pairs of columns supporting a small cornice with low pyramids arranged on it. The altar was consecrated on 6th February, 1932 (Cloister's Chronicle).

The altar of St. Joseph, constructed at the same time (Głos Karmelu, 1932) was remodelled following designs by Józef Dudkiewicz, Eng. In its retable, cut in Carrara marble and grey, brecciated Zhuravno alabaster by Edward Jamrozik, a stonemason, there is a picture of St. Joseph, the Betrothed of the Blessed Virgin Mary, the patron saint of the City of Kraków. The retable forms a rectangular slab with a triangular termination, topped with a small cross. In the niche of the semi-circular antependium is a relief representing the scene of St. Joseph's death, surrounded by figures of Jesus Christ and St. Mary, sculpted in white Zhuravno alabaster and in places with grey and brownish colours. A similar presentation can be found in the antependium of the main altar of the church of Discalced Carmelite nuns in Kraków, at Łobzowska Street (Wanat, 1981).

The whole pulpit is lined with slabs of various types of Podolian alabaster. The pulpit body is ornamented with the sculptures of four saints: Mark, Lukas, John and Matthew, cut by J. Horodyska in white alabaster (Fig. 17). They are arranged in pairs against an inlaid black background; in each pair one figure is shown en face and the other in profile with the Evangelist's head slightly inclined. The figures of the Evangelists, full of solemnity and with their faces expressing meditation and humility, are dressed in long, folded robes; at their feet rest their symbols: a winged lion, a winged bull, an eagle and a winged human (Smirnow, 2005). Each of the statues cost 180 Polish zloty (Cloister's Chronicle). The body, the canopy and basis of the pulpit, and the wall protecting the pulpit stairs was lined with veined alabaster. The balustrade is divided into fields, within which small poles narrow going upwards, as if to form stairs. The whole pulpit is covered by a canopy with a small cross.

Next to the altar of St. Thérèse stands a small, $3 \mathrm{~m}$ high shrine of St. Anthony of Padua, a preacher and theologist, who supports the baby Jesus with his hand. Except for the figure of the saint, the remaining parts were made of grey and white alabasters. The canopy of this small shrine rests on corbels and is topped by a pedestal carrying a cross (Wiśniewska, 1997).

Following the design of F. Mączyński, the side chapels are located under the choir loft. The Zhuravno alabaster workshop manufactured the altar for the Chapel of the Child Jesus in 1934, and in 1936 another for the Chapel of Our Lady the
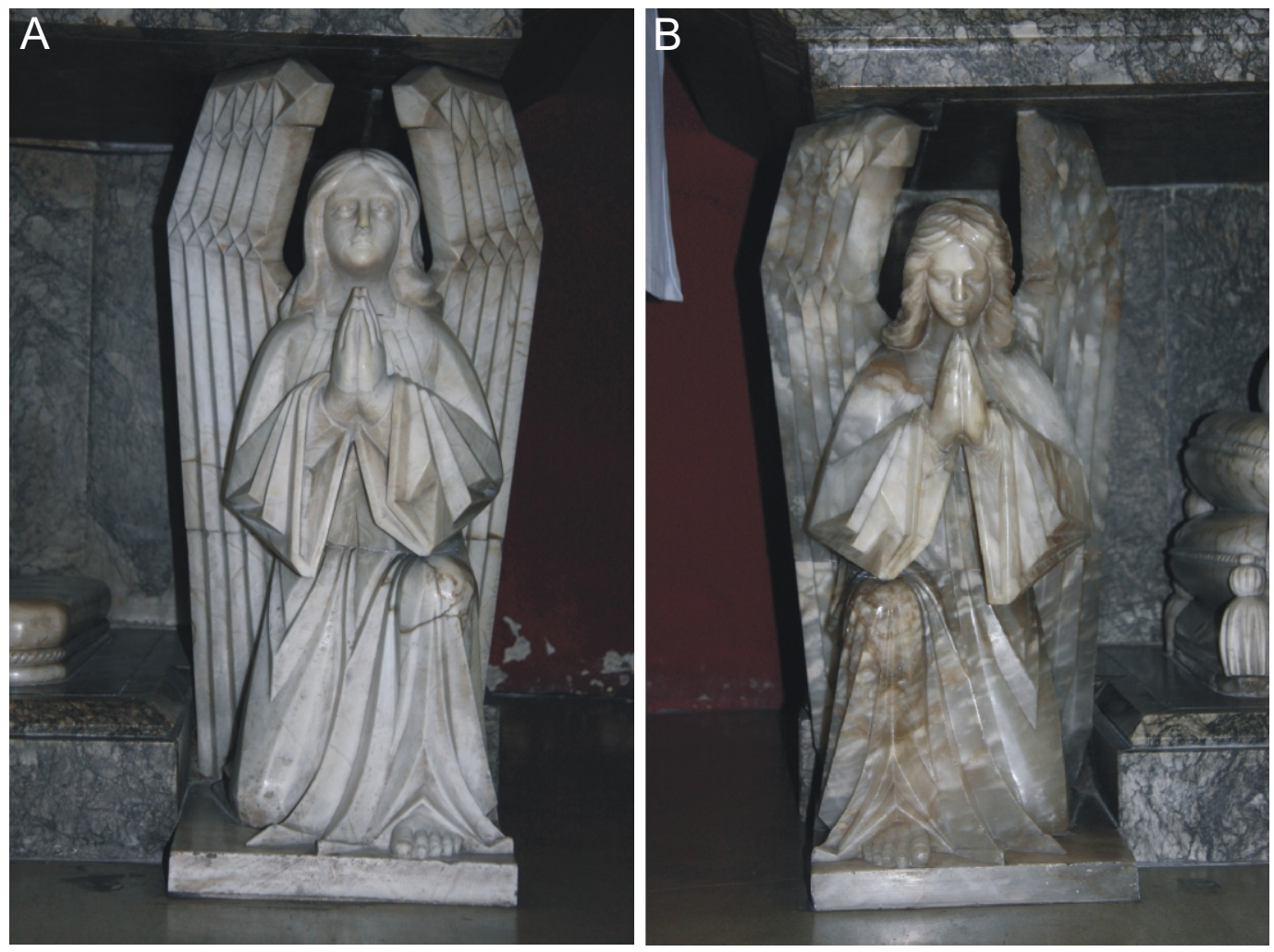

Fig. 16A, B - church of Discalced Carmelites, Rakowicka Street, Kraków; the altar of St. Thérèse: the kneeling angels support the mensa; alabaster of Zhuravno, sculptor: Bertini 


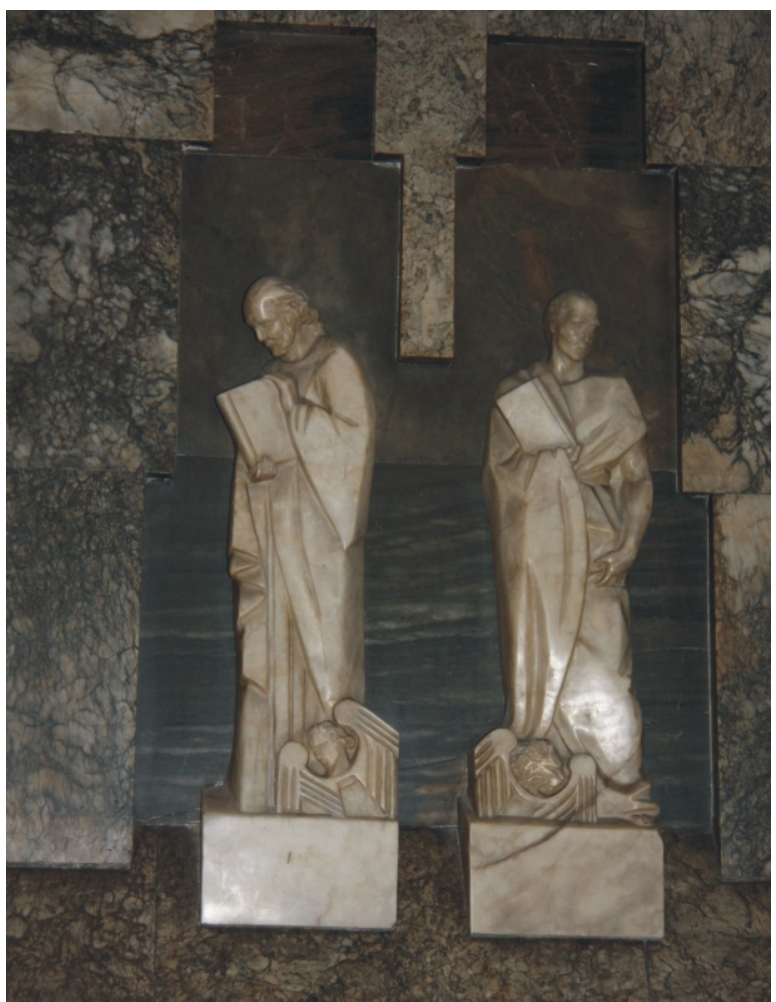

Fig. 17. Church of Discalced Carmelites, Rakowicka Street, Kraków; a fragment of the pulpit with figures of apostles; Alabaster of Zhuravno, sculptress: J. Horodyska

Photo by J. Rajchel

Mother of Sorrows. Both altars were designed by J. Szostakiewicz, Eng., who was paid 3800 and 3500 Polish zloty, respectively (Cloister's Chronicle).

In the Chapel of the Child Jesus, white alabaster can be seen in almost the whole predella and antependium of the altar, while grey alabaster lines the mensa and its side walls (Fig. 18). The retable, placed on a high plinth, forms a semi-closed arcade. In the centre is a niche, topped with a crown, in which there is a figurine of Jesus as a child. The figurine is surrounded by a kind of radial glory, enriched in its upper part by flower garlands. On the plinth stands bas-reliefs of St. Stanislaus Kostka and St. Thérèse of the Child Jesus, accompanied by small children (Wiśniewska, 1997).

The altar of Our Lady the Mother of Sorrows, located on the left of the church was sculpted in grey, brecciated and white alabasters (Fig. 19). The middle part of a plinth is occupied by a tabernacle made of honey-yellow alabaster, which is flanked by two columns with stone sphere terminations. Above them, a painting shows Our Lady, with a sword piercing her heart (Zawada, 2009). The composition has a frame made of a profiled, grey alabaster, topped with a crown and a cross. In the upper part of the arcaded retable, small branches of stylized roses with rays are cut in grey alabaster. On the left side of the retable is the monogram IHS and the burning heart entwined by the crown of thorns. On the right side was sculpted the symbol of Our Lady, with the heart pierced by a sword above it. These elements were cut in white alabaster.

The back and side walls of the chancel were lined up to half-way with a brownish alabaster, forming an excellent background to the main altar. The brownish alabaster was used for facings of the pillars in the main nave and for a holy water stoup.

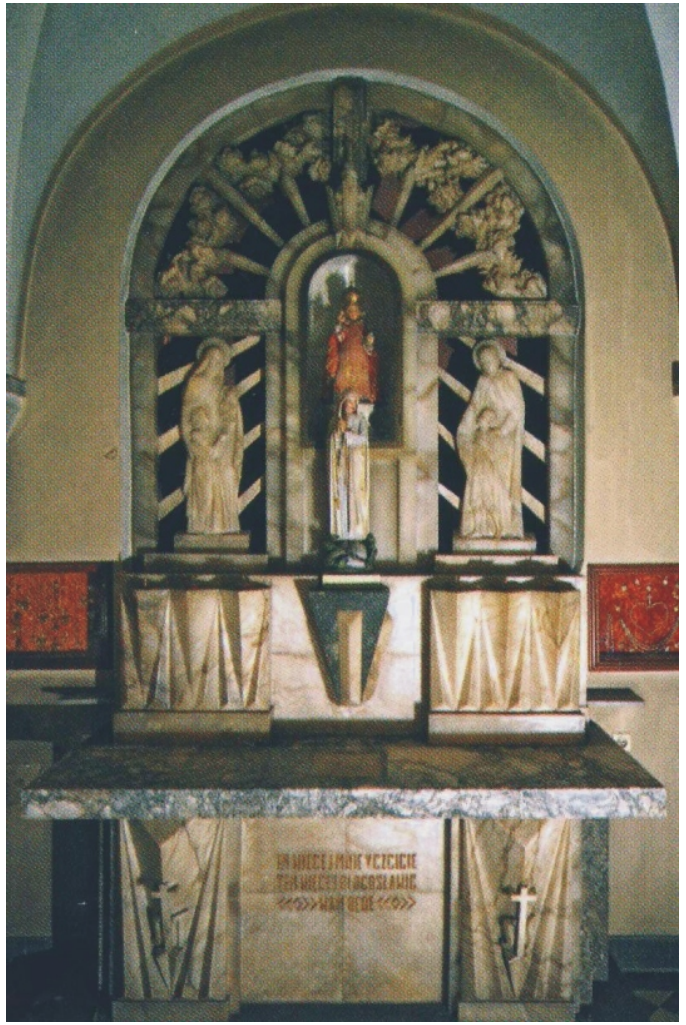

Fig. 18. Church of Discalced Carmelites, Rakowicka Street, Kraków; the altar in the Chapel of the Child Jesus; alabaster of Zhuravno, sculptress: J. Horodyska (archive of Discalced Carmelite fathers)

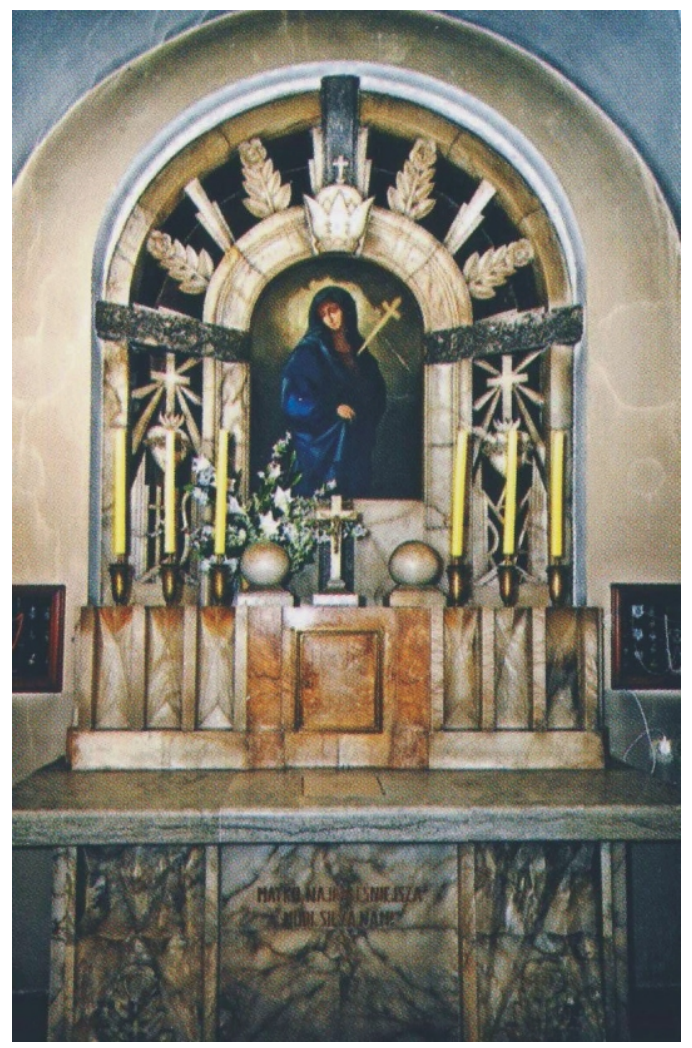

Fig. 19. Church of Discalced Carmelites, Rakowicka Street, Kraków; the altar in the Chapel of Our Lady, the Mother of Sorrows; alabaster of Zhuravno; sculptress: J. Horodyska (archive of Discalced Carmelite fathers) 


\section{ALABASTER IN SELECTED SECULAR OBJECTS}

In the late architecture of Kraków alabaster was used as a decorative stone, mainly in works of the 2nd half of the 19th century and in Poland for twenty years after World War I had ended. The specified time frames mark the periods of the revival of interest in "Ruthenian" alabaster. Interest was strongest in the 1920s and the 1930s, when the Polish economy was based on supporting domestic products; "Ruthenian marble" best fulfilled this requirement. The stone was used to make figural sculptures, balustrades, fireplaces, stone spheres, columns, posts, vases, other small architectonic details, and also used in the manufacture of façade slabs and floor tiles. Artisans skillfully combined the colour and structural varieties of alabaster with valuable varieties of wood and metal (e.g., chromium, brass) to obtain a perfect match. The integration of economics and an esthetic approach resulted in unusual interior designs. Expansion of many Polish towns by the architects of the Lviv provenience added to the popularity of the Dnister-side alabaster. We can find it both in older tenement houses and in many public buildings; this is true for both metropolises (Kraków and Lviv) and small towns throughout the whole historical Lesser Poland region (for instance Lutsk, Chernivtsi, Rzeszów, Jasło, Sanok, Krynica, Żegiestów, Przemyśl), and also elsewhere in Poland (e.g., Katowice, Gdynia, Warszawa). Alabaster had become fashionable. However, finding such applications of alabaster today, particularly in tenement houses, is very difficult; additionally, the stones' sites of origin as proved by original documents can be identified in only a few cases.

\section{PUBLIC UTILITY EDIFICES}

The prestige commissions of the Alabastrownia Workshop of Count Czartoryskis' family at Zhuravno include in Kraków public utility edifices, such as the building of the former Communal Savings Bank of the Cracow District at no. 1, Pijarska Street, which is currently occupied by the Pekao Bank S.A., or the building of the Jagiellonian Library at No. 24, Mickiewicza avenue.

The building of the former Communal Savings Bank of the Cracow District was constructed in 1897-1899 and was designed by the architects Tadeusz Stryjeński and Zygmunt Hendel, in the style of classicizing secession. The building also housed the offices of the District Council. Of the original alabaster inner décor, the only extant is the wall facing of a staircase, a sill parapet of the stained-glass window on a landing and ornamented pilasters of a side staircase, all cut in brecciated, ash grey alabaster to form rectangular slabs with dimensions $29 \times$ 29 or $25 \times 31 \mathrm{~cm}$.

Distinctly richer and fully preserved are the alabaster decorations of the Jagiellonian Library (Rajchel, 2005). The building was constructed in 1931-1939 and was designed by Wacław Krzyżanowski, a renowned Cracow architect. Following the example of other monumental Cracow buildings from that period, its stone decor is composed almost exclusively of domestic rocks, including alabaster (Fig. 20). The alabaster used came from Zhuravno, and is light yellow and brecciated, with darker, irregular small veins and spots. The rock was cut into facing slabs that line the staircase as high as the second floor; the large, rectangular slabs have a deep concave relief. The same alabaster was used in ornamental balustrades and railings, and also makes the cornice of the wall - the one with the entrance leading to the staircase. Simultaneously, the walls of the vestibule and many other rooms have stucco decorations which imitate the colour of alabaster (Heflik, 1989).

\section{CONCLUSIONS}

Today, alabaster is a forgotten decorative stone. It is the authors intention to turn attention towards the wealth of alabaster applications in historical and almost current architectural works, and to get masons and architects interested in the alabaster variety from Podolia, which is an excellent decorative stone but remains "in disgrace". Due to its technical parameters, rich spectrum of colours, high accessibility and cheap prices compared with other decorative stones, this alabaster has a considerable chance to re-enter the stone market. It seems that it is worth returning to the tradition of using this beautiful rock, especially considering that reserves of gypsum and alabaster in Poland, and mainly in Ukraine, are enormous.

At the same time, there is demand for precise information on the provenance of alabaster used in historic sites, important for art historians, architects and specialists active in stone revalorization and conservation. Thus, the authors cherish the hope that this paper may be helpful both in research and practice.

Acknowledgements. The authors thank T.M. Peryt (PGI-NRI) for his help, valuable advice, suggestions and instructions, particularly those pertaining to fieldwork in Ukraine. We also thank Dr. A. Poberezhsky and Dr. O. Stupka (Institute of Geology and Geochemistry of Combustible Minerals, the National Academy of Sciences of Ukraine), for their important observations and help in carrying out the field campaign in the quarrying operations of their country. We thank the reviewers of our article-Ms Prof. Dr. A. Lipińska, Technische Universität Berlin, Institut für Historische und Kunstwissenschaft Urba- 
nistik, Fachgebiet Kunstgeschichte and again Dr. A. Poberezhsky of the Institute of Geology and Geochemistry of Combustible Minerals of the National Academy of Sciences of Ukraine in Lviv for their in-depth study of our article and very important recommendations aimed at improving its scientific value. We are indebted to Dr. B. Duchess Czartoryska of the Institute of Psychiatry and Neurology, Genetics Department in Warsaw for her kind care and help in collecting information on the Alabastrownia Workshops at Żurawno, owned by her parents $\mathrm{H}$. Duchess Czartoryska (née Skrzyńska) and K. Duke Czartoryski. The paper has been prepared at the AGH Stanisław Staszic University of Science and Technology in
Cracow, the Faculty of Geology, Geophysics and Environment Protection, the Chair of General Geology and Geotourism, within the statutory research No's 11.11.140.747 and 11.11.140.173 and author's own investigations No. 10.10.140.575, and was also supported by the supervisory research project No. NN 525348138 of the Ministry of Science and Higher Education. M. Wardzyński's researches were developed at the Institute of Art History, University of Warsaw, as part of the supervisory scientific grant No. N N105 133939 of the National Science Centre, Poland.

\section{REFERENCES}

Agfanova, T.N., Nazarenko, V.V., Gutnichenko, G.K., 1968. Patterned alabaster of Pridnestrovya (in Russian). Izvestia Vysshykh Uchebnykh Zavedeniy, Geologiya i Razvedka, 8: 82-86.

Akerman, K., 1964. Gips i anhydryt. Występowanie i zastosowanie w przemyśle i budownictwie (in Polish). Wyd. PWN, Warszawa.

Andreyeva-Grigorovich, A.S., Kulchytsky, Y.O., Gruzman, A.D., Lozynyak, P.Y., Petrashkevich, M.I., Portnyagina, L.O., Ivanina, A.V., Smirnov, S.E., Trofimovich, N.A., Savitskaya, N.A., Shvareva, N.J., 1997. Regional stratigraphic scheme of Neogene formations of the Central Paratethys in the Ukraine. Geologica Carpathica, 48: 123-136.

Babel, M., 2005. Event stratigraphy of the Badenian selenite evaporites (Middle Miocene) of the northern Carpathian Foredeep. Acta Geologica Polonica, 55: 9-29.

Betlej, A., 1996. Nieznany projekt nagrobka Jana Aleksandra Lipskiego (in Polish). Studia Waweliana, 5: 191-192.

Betlej, A., 2007. Kilka uwag na temat przekształcenia kaplicy Lipskich przy katedrze krakowskiej w XVIII wieku (in Polish). In: Artifex Doctus. Studia ofiarowane profesorowi Jerzemu Gadomskiemu w siedemdziesiata rocznice urodzin. Kraków, 1: 301-312.

Bevz, M., 2000. "Ruskiy marmur" - koshtovna prykrasa L'vova (in Ukrainian). Galytska Brama, 8/68: 2-3

Bochnak, A., Samek, J., eds., 1971. Katalog zabytków sztuki w Polsce (in Polish). Vol. IV, Warszawa.

Bunkiewicz, W., 1934. Sztuka Żurawieńska (in Polish). Kurjer Warszawski, 227: 14-15.

Chrzanowski, T., 2008. Sztuka w Polsce od I do III Rzeczypospolitej (in Polish). Wyd. PWN, Warszawa.

Czyżewski, K., 2002. Królewska Katedra na Wawelu - przewodnik (in Polish). Wyd. św. Stanisława BM Archidiecezji Krakowskiej, Kraków.

Darnowska-Łukaszewska, J., 1997. O przypadkowej genezie formy nagrobka Montelupich w kościele Mariackim w Krakowie (in Polish). In: Między gotykiem a barokiem. Sztuka Krakowa XVI i XVII wieku. Materiały sesji naukowej zorganizowanej przez Odział krakowski. Stowarzyszenie Historyków Sztuki, 20.03.1993 (ed. E. Fiałek): 93-94, Kraków.

Dettloff, P., 2012. Ołtarzowe mauzoleum bł. Stanisława Kazimierczyka (in Polish). In: Błogosławiony Stanisław Kazimierczyk kanonik regularny laterański (1433-1489). Postać - środowisko - kultura - dziedzictwo. Materiały międzynarodowej konferencji naukowej, Kraków, 7-8 maja 2010 (ed. K. Łatek): 324-342, Kraków.

Dorosh, A., 2000. Alebastrovi vyroby z Zhuravna (in Ukrainian). Galytska Brama, 8: 10-11.

Dromashko, S.G., 1955. K mineralogii gipsiv Prydnestrovya (in Ukrainian). Voprosy Mineralogii Osadochnykh Obrazovaniy, 2 : 138-174.

Fischinger, A., 1969. Santi Gucci architekt i rzeźbiarz królewski XVI wieku (in Polish). Wyd. Ministerstwo Kultury i Sztuki, Zarząd Muzeów i Ochrony Zabytków, Warszawa.
Flasza, J., 1998. Bochnia, przewodnik po mieście (in Polish). Urząd Miejski, Bochnia.

Gajewski, E., 1989. “...drugiemu nie da!” (in Polish). Nowiny Rzeszowskie, 54: 1-8.

Galicka, I., Smulikowska-Rowińska, E., 1961. Powiat kraśnicki. Katalog zabytków sztuki w Polsce (in Polish) (eds. R. Brykowski, E. Smulikowska and Z. Winiarz), 8, Warszawa.

Garlicki, A., 1962. Budowa geologiczna rejonu złoża gipsu alabastrowego w Łopuszce Wielkiej (in Polish). Kwartalnik Geologiczny, 6 (4): 758-759.

Gębarowicz, M., 1962. Studia nad dziejami kultury artystyczne późnego renesansu w Polsce (in Polish). Prace Wydziału Filologiczno-Filozoficznego, Toruń, 13: 354-362.

Gębarowicz, M., 1969. Artyści - przedsiębiorcy epoki renesansu (in Polish). Biuletyn Historii Sztuki, 31: 257-275.

Glyembotska, G., 2000. Alebastrovi epitafii kaplytsi Boimiv (in Ukrainian). Galytska Brama, 8: 12-15.

Głos Karmelu, 1932. Wyd. oo. Karmelitów Bosych w Krakowie, 6.

Grankin, P., 2000. Alebastr v interyerakh Ivyvskykh kamyanyts mizhvoyennoho dvadtsyatyrychchya 1920-1939 gg. (in Ukrainian). Galytska Brama, 8: 18-20.

Heflik, W., 1989. Kamienie ozdobne Polski (in Polish). Wyd. Geol., Warszawa.

Heflik, W., Natkaniec-Nowak, L., 1996. Gemmologia, czyli nauka o kamieniach szlachetnych i ozdobnych (in Polish). Wyd. Antykwa, Kraków.

Heflik, W., Natkaniec-Nowak, L., Pieczka, A., 1996. Kamienie szlachetne i ozdobne Polski (in Polish). Wyd. AGH, Kraków.

Hornung, Z., 1956. Materiały do dziejów stosunków artystycznych polsko-ślaskich w XVI i XVII wieku (in Polish). Sprawozdania Wrocławskiego Towarzystwa Naukowego, 10. Dodatek 1: 8-9, 14-16, 21, 23 .

Jagnyshchak, V., 1994. Marmurovy perlyny Zhuravno (in Ukrainian). Galytska Brama, 3: 6.

Jagnyshchak, V., 1996. Alebastr w istorii Zhuravna (in Ukrainian). Galytska Brama, 13: 8.

Jagnyshchak, V., 2000. XX stolittya Zhuravno (in Ukrainian). Galytska Brama, 8: 16-17

Janeczek, J., Kozłowski, K., Żaba, J., 1991. Zbieramy minerały i skały. Przewodnik po Dolnym Śląsku (in Polish). Wyd. Geol., Warszawa.

Karpowicz, M., 2002. Andrea i Antonio Castelli rzeźbiarze krakowscy XVII w (in Polish). Edition by the author, Warszawa,

Karpowicz, M., 2003. Chronologia i geografia niderlandyzmu w rzeźbie 1. połowy XVII wieku (in Polish). In: Niderlandyzm na Śląsku i w krajach ościennych (eds. M. Kapustka, A. Kozieł and P. Oszczanowski): 43-53. Wyd. Uniwersytetu Wrocławskiego.

Kasprzyk, A., 1993. Lithofacies and sedimentation of the Badenian (Middle Miocene) gypsum in the northern part of the Carpathian Foredeep, southern Poland. Annales Societatis Geologorum Poloniae, 63: 33-84. 
Kasprzyk, A., 1995. Correlation of sulphate deposits of the Carpathian Foredeep at the boundary of Poland and Ukraine. Geological Quarterly, 39 (1): 95-108.

Koltun, W.I., Roskosh, J.T., 1969. Ob usloviyakh obrazovaniya gipsov i angidritov Pridniestrovya (in Russian). Voprosy litologii i petrografii, Lvov, 1: 172-176.

Korpysz, E., 2007. A Child's Tomb from Dobromyl' (Ukraine) (in Polish with English summary). Biuletyn Historii Sztuki, 69: 115-124.

Korpysz, E., 2008. The Piscina preserved in Dobromil (in Polish with English summary). Biuletyn Historii Sztuki, 70: 359-384.

Kowalczyk, J., 1987. Le monument funéraire d'Anne Jagellon dans la chapelle de Sigismond B la cathédrale de Cracovie (in Polish with French abstract). Folia Historiae Atrium, 23: 5-22.

Kozakiewiczowa, H., 1983. Renaissance in Poland. Jan Maria Mosca known as Padovano (in Polish). Wyd. Arkady, Warszawa.

Kozakiewiczowa, H., 1984. Rzeźba XVI wieku w Polsce (in Polish). Wyd. PWN, Warszawa.

Kozłowski, S., 1986. Surowce skalne Polski (in Polish). Wyd. Geol., Warszawa.

Krajewski, R., Smulikowski, K., 1964. Zarys nauki o złożach kopalin użytecznych (in Polish). Wyd. Geol., Warszawa.

Krakowski, P., 1957. Pomnik nagrobny ks. Ostrogskich (in Polish). Studia renesansowe, 2: 263-302.

Kwiatkowska, M., 1993. Polscy rzeźbiarze w Rzymie (in Polish). In: Między Polską a Światem. Od średniowiecza po lata II wojny światowej (eds. M. Marki and P. Paszkiewcz): 57-100. Wyd. Kragg, Warszawa.

Kwiatkowski, S., 1972. Sedimentation of gypsum in the Miocene of Southern Poland (in Polish with English summary). Prace Muzeum Ziemi, 19: 3-93.

Kwiatkowski, S., 1974. Miocene gypsum deposits in southern Poland (in Polish with English summary). Biuletyn Instytutu Geologicznego, 280: 299-336.

Lipińska, A., 2003. Alabastrum efforditur pulcherrimum and candissimum. Wpływ południowoniderlandzkich centrów rzeźby na popularyzację alabastru na przykładzie Polski, Śląska i Saksonii. In: Centrum i peryferie. Materiały III Ogólnopolskiej Sesji Studenckiej (ed. A. Lipińska): 73-75. Wyd. Uniwersytetu Wrocławskiego.

Lipińska, A., 2007. Wewnętrzne światło (in Polish). Południowoniderlandzka rzeźba alabastrowa w Europie Środkowo-Wschodniej. Wrocław.

Lipińska, A., 2011. Matter of light and flesh: alabaster in the Netherlandish sculpture of the 16th and 17th centuries. In: Matter of light and flesh: alabaster in the Netherlandish sculpture of the 16th and 17th centuries (eds. J. Kriegseisen and A. Lipińska): 12-61. Katalog wystawy, Muzeum Narodowe w Gdańsku, Oddział Zielona Brama, 15.11.2011-15.03.2012, Gdańsk.

Lyubchenko, V.F., 1981. Lvivska skulptura XVI-XVII stolit (in Ukrainian). Naukova Dumka, Kyiv.

Łoziński, W., 1901. Sztuka Iwowska w XVI I XVII wieku (in Polish). Architektura i rzeźba. Wyd. Księgarni H. Altenberga, Lwów.

Łoziński, J.Z., 1970. Grobowe kaplice kopułowe w Polsce 1520-1620. PWN, Warszawa.

Mańkowski, T., 1948. De la renaissance italienne a la renaissance septentrionale (in Polish with French abstract). Biuletyn Historii Sztuki i Kultury, 3: 257-284.

Markham-Schulz, A., 1998. Gianmaria Mosca called Padovano a Renaissance sculptor in Italy and Poland. Pennsylvania State University Press, 1: 121-160.

Maurin-Białostocka, J., 1979. Hutte van Herman zw. Czapką. In: Słownik artystów polskich i obcych w Polsce działających (zmarłych przed 1966) (eds. J. Maurin-Białostocka and J. Derwojed), 3: 138-139, Wrocław.

Mitrofanov, G.K., Shpanov, I.A., 1970. Oblitsovochnyye i podyelochnyye kamni SSSR (in Russian). Izdatielstvo Niedra, Moskva.

Nowak, J., 1938. Der Dniestr Fluss und die tortonen Gipse (in Polish with German summary). Rocznik Polskiego Towarzystwa Geologicznego, 14: 153-194.

Nowak, J.T., Turdza, W., 2007. Treasures of the Cracow monasteries. 750th anniversary of the death of Saint Hyacinth. The col- lection of the Dominican monastery) (in Polish with English summary). Muzeum Historyczne Miasta Krakowa. Wrocław-Warszawa-Kraków-Gdańsk, Zakład Narodowy imienia Ossolińskich, Wyd. PAN.

Peryt, T.M., 1996. Sedimentology of Badenian (middle Miocene) gypsum in eastern Galicia, Podolia and Bukovina (West Ukraine). Sedimentology, 43: 571-588.

Peryt, T.M., 2001. Gypsum facies transitions in basin-marginal evaporites: middle Miocene (Badenian) of West Ukraine. Sedimentology, 48: 1103-1119.

Peryt, T.M., 2006. The beginning, development and termination of the Middle Miocene Badenian salinity crisis in Central Paratethys. Sedimentary Geology, 188-189: 379-396.

Peryt, T.M., 2013. Palaeogeographical zonation of gypsum facies: Middle Miocene Badenian of Central Paratethys (Carpathian Foredeep in Europe). Journal of Palaeogeography, 2: 225-237.

Peryt, T.M., Hałas, S., Karoli, S., Peryt, D., 1997. Isotopic record of environmental changes during deposition of Badenian (Middle Miocene) gypsum at Kobeřice near Opava (Czech Republic) (in Polish with English summary). Przeglad Geologiczny, 45: 807-810.

Peryt, T.M., Durakiewicz, T., Peryt, D., Poberezhskyy, A., 2012. Carbon and oxygen isotopic composition of the Middle Miocene Badenian gypsum-associated limestones of West Ukraine. Geologica Acta, 10: 319-332.

Petrichenko, O.I., Peryt, T.M., Poberegski, A.V., 1997. Pecularities of gypsum sedimentation in the Middle Miocene Badenian evaporite basin of Carpathian Foredeep. Slovak Geological Magazine, 3: 91-104.

Popovych, J., 2000. Deyaki aspekty technologichnogo vyvchennya alebastrovoi skulptury (in Ukrainian). Galytska Brama, 8: 4-5.

Przybyszewski, B., 2012. Katedra krakowska w XVIII wieku (in Polish). Archiwum i Biblioteka Krakowskiej Kapituły Katedralnej, Kraków.

Rajchel, J., 2002. Alabaster - forgotten decorative stone (in Polish). Świat Kamienia, 3: 74-77.

Rajchel, J., 2005. Cracow of stone: geologist's look (in Polish). Uczelniane Wydawnictwa Naukowo-Dydaktyczne, Kraków.

Rejduch-Samkowa, I., Samek, J., 1987. Katalog Zabytków Sztuki w Polsce (ed. J. Szablowski) (in Polish). Vol. IV. Wyd. Artystyczne i Filmowe, Warszawa.

Rożek, M., 1977. Mecenat artystyczny mieszczaństwa krakowskiego w XVII wieku (in Polish). Wyd. WAM, Kraków.

Rożek, M., 1980. Katedra Wawelska w XVII wieku (in Polish). Wyd. Literackie, Kraków.

Rożek, M., 2010a. Przewodnik po zabytkach Krakowa (in Polish). Kraków.

Rożek, M., 2010b. Idee i symbole sztuki chrześcijańskiej (in Polish). Wyd. WAM, Kraków.

Rychlicki, J., 1913. Über die hypsometrische Lage der Gipsablaberungen am südwestlichen Rande des podolischen Plateau (in Polish with German summary). Kosmos, 38: 179-202.

Senkovskyi, J.M., 1972. Litogenez sirchanych rodovyshch Prykarpattya (in Ukrainian). Naukova Dumka, Kyiv.

Siemiradzki, J., 1922. Płody kopalne Polski (in Polish). Wiedza Współczesna, 6. H. Altenberg, Księgarnia Wydawnicza we Lwowie, Lwów.

Sinko-Popielowa, K., 1946. Zaginiony nagrobek św. Jacka w kościele oo. dominikanów w Krakowie (in Polish). Prace Komisji Historii Sztuki, 8: 325-326.

Skalmowski, W., 1959. Die gipsen und anhydriten in Polen. Die möglichkeiten und richtungen ihrer ausnützung im bauwesen (in Polish with Germany summary). Studia z zakresu budownictwa, 4: 1-87. Wyd. PWN, Warszawa.

Smirnow, J., 2005. Jadwiga Horodyska. Życie i twórczość artystyczna (in Polish). Edition by the author, Lwów.

Smyrnov, J., 2000. Alebastrovi vivtari ta nagrobky y latynskomu kafiedralnomu sobori (in Ukrainian). Galytska Brama, 8: 6-9.

Syemchuk, S.A., Kshanovskiy, O.V., 1984. Obzor syrevoy bazy promyshlennosti storoitelnykh materialov Ivovskoy oblasti USSR (in Russian). Ministry of Geology of the USSR, Lvov. 
Syomochkyn, I., 2000. Alebastrovi pamyatnyky dominikanskogo soboru (in Ukrainian). Galitskiya Brama, 8: 15-16.

Syomochkyn, I., Jagnyshchak, W., 1999. De alabastro Dnystriense laborandum est (vygotovlyeno z naddnistryanskogo alebastru) (in Ukrainian). Buduyemo inakshe, 5: 13-20.

Szajnocha, K., 1901. Szkice historyczne (in Polish). Nakładem Słowa Polskiego, Lwów, 3.

Tatarkiewicz, W., 1953. Czarny marmur w Krakowie. Prace Kom. Historii Sztuki PAU, 10/1, Kamieniarstwo, Kraków.

Targosz, K., 1991. Mausolée de l'évèque Jacques Zadzik dans la cathédrale de Cracovie (in Polish with French summary). Studia do Dziejów Wawelu, 5: 237-308.

Tomkowicz, S., 1912. Przyczynki do historii kultury artystycznej Krakowa w I poł. XVII w (in Polish). Towarzystwo dla Popierania Nauki Polskiej. Archiwum Naukowe, Lwów, 5.

Tyrowicz, S., 1977. Kamień w zabytkach średniowiecznego Krakowa (in Polish). Manuscript, Kraków.

Wanat, B.J., 1981. Kult św. Józefa, oblubieńca NMP u Karmelitów Bosych w Krakowie (in Polish). Wydawnictwo oo. Karmelitów Bosych.

Wardzyński, M., 2010a. "Ruthenian alabasters". The history of exploitation and application in architecture and sculptures in 16th century Ruthenia, Poland and Silesia (in Polish with English summary). In: Między Wrocławiem i Lwowem. Sztuka na Ślasku, w Małopolsce i na ziemiach ruskich Korony od XVI do XVIII wieku (eds. A. Betlej, K. Brzezina and P. Oszczanowski): 339-358. Wyd. Uniwersytetu Wrocławskiego.

Wardzyński, M., 2010b. Between Italy and the Low Countries. Centres of stonemasonry and sculpture in Central Europe and the early modern tradition. Some remarks on material and technol- ogy (in Polish with English summary). In: Material of Sculpture. Between Technique and Semantics (ed. A. Lipińska): 425-455. Wyd. Uniwersytetu Wrocławskiego.

Wardzyński, M., 2012a. Artifices chencinenses. Rola i miejsce warsztatów chęcińskich w produkcji kamieniarsko-rzeźbiarskiej w Rzeczypospolitej (koniec XVI-1. połowa XVII wieku) (in Polish). In: Franciszka z Krasińskich Wettyn, księżna Kurlandii i Semigalii, prababka dynastii królów włoskich. Dziedzictwo rodziny Krasińskich w regionie świętokrzyskim (eds. D. Kalina, R. Kubicki and M. Wardzyński): 151-184. Urząd Marszałkowski Województwa Świętokrzyskiego.

Wardzyński, M., 2012b. Organizing the work and workshop practice in the Krakow and Dębnik quarries between the second quarter of the 17 th century and the beginning of the 18th century and the "long lasting" of the late-Mannerist and early-Baroque forms (in Polish with English abstract). In: Studia nad sztuka renesansu i baroku (eds. I. Rolska-Boruch and K. Gombin), 11: 331-381. Towarzystwo Naukowe KUL, Lublin.

Wiśniewska, J., 1997. Architektura i wystrój kościoła oo. Karmelitów Bosych w Krakowie przy ul. Rakowickiej 18 (in Polish). Praca mgr. Seminarium z historii sztuki kościelnej PAT w Krakowie, Wydział Historii Kościoła, Kraków.

Woźniak, D., 1964. Polska rzeźba plenerowa (in Polish). Muzeum Ślaska Opolskiego w XX-lecie PRL, Opole.

Zawada, M., 2009. Ogród Boży pośród miasta. In: 100-lecie Klasztoru Karmelitów Bosych przy ul. Rakowickiej w Krakowie (ed. M. Zawada). Wydawnictwo Karmelitów Bosych, Kraków.

Żaba, J., 2006. Ilustrowana encyklopedia skał i minerałów (in Polish). Wyd. Videograf II, Katowice. 